\title{
Obstructive Sleep Apnea and Diabetes
}

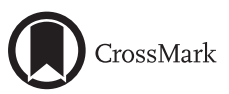

\section{A State of the Art Review}

Sirimon Reutrakul, MD; and Babak Mokhlesi, MD

OSA is a chronic treatable sleep disorder and a frequent comorbidity in patients with type 2 diabetes. Cardinal features of OSA, including intermittent hypoxemia and sleep fragmentation, have been linked to abnormal glucose metabolism in laboratory-based experiments. OSA has also been linked to the development of incident type 2 diabetes. The relationship between OSA and type 2 diabetes may be bidirectional in nature given that diabetic neuropathy can affect central control of respiration and upper airway neural reflexes, promoting sleep-disordered breathing. Despite the strong association between OSA and type 2 diabetes, the effect of treatment with CPAP on markers of glucose metabolism has been conflicting. Variability with CPAP adherence may be one of the key factors behind these conflicting results. Finally, accumulating data suggest an association between OSA and type 1 diabetes as well as gestational diabetes. This review explores the role of OSA in the pathogenesis of type 2 diabetes, glucose metabolism dysregulation, and the impact of OSA treatment on glucose metabolism. The association between OSA and diabetic complications as well as gestational diabetes is also reviewed.

CHEST 2017; 152(5):1070-1086

KEY WORDS: central sleep apnea; diabetic complications; gestational diabetes; OSA; sleep apnea; type 1 diabetes; type 2 diabetes; weight loss

OSA is a treatable chronic sleep disorder characterized by recurrent episodes of complete (apnea) or partial (hypopnea) obstruction of the upper airway causing intermittent hypoxemia and hypercapnia, cortical microarousals, increased oxidative stress, inflammation, and sleep fragmentation. These adverse effects of OSA are important mediators of metabolic, cardiovascular, and neurocognitive risk. ${ }^{1}$ The prevalence of OSA has been increasing in parallel with the obesity epidemic.

Population-based studies using older diagnostic criteria for OSA reported a prevalence of moderate to severe OSA of $4 \%$ to $7 \%$ and $9 \%$ to $14 \%$ in middle-aged women and men, respectively. ${ }^{2-6}$ However, a more recent study using current diagnostic definitions reported a substantially higher prevalence of moderate to severe OSA of $23 \%$ in women and $49 \%$ in men. ${ }^{1}$ Therefore, one could surmise that the current prevalence of OSA is reflecting not only the prevalence of obesity but also the use of more sensitive polysomnographic techniques and scoring criteria. Importantly, using the
ABBREVIATIONS: AHI = apnea-hypopnea index; GLP-1 = glucagonlike peptide 1 ; HbAlc $=$ hemoglobin Alc; HOMA = homeostatic model assessment; IVGTT = IV glucose tolerance test; OGTT = oral glucose tolerance test; REM = rapid eye movement

AFFILIATIONS: From the Division of Endocrinology and Metabolism (Dr Reutrakul), Department of Medicine, Faculty of Medicine, Ramathibodi Hospital, Mahidol University, Bangkok, Thailand and the Division of Endocrinology, Diabetes and Metabolism (Dr Reutrakul), Department of Medicine, University of Illinois College of Medicine at Chicago, Chicago, IL; and the Section of Pulmonary and Critical Care
(Dr Mokhlesi), Sleep Disorders Center, Department of Medicine, The University of Chicago, Chicago, IL.

CORRESPONDENCE TO: Babak Mokhlesi, MD, Section of Pulmonary and Critical Care, Sleep Disorders Center, The University of Chicago, 5841 S Maryland Ave, MC6076/Room M630, Chicago, IL 60637-1470; e-mail: bmokhles@medicine.bsd.uchicago.edu

Copyright (C) 2017 American College of Chest Physicians. Published by Elsevier Inc. All rights reserved.

DoI: http://dx.doi.org/10.1016/j.chest.2017.05.009 
most recent scoring criteria reconfirmed the strong associations between OSA and relevant comorbidities such as type 2 diabetes, metabolic syndrome, hypertension, cardiovascular disease, and depression. ${ }^{1}$

As with OSA, the prevalence of diabetes is also increasing in the United States and worldwide. Type 2 diabetes represents $90 \%$ to $95 \%$ of all cases of diabetes. In the past 3 decades, the number of American adults with diabetes nearly quadrupled, with an estimated 29 million people or $9.3 \%$ of the population of the United States estimated to have diagnosed or undiagnosed diabetes. ${ }^{7}$ Each year, more than 200,000 deaths occur among people with diabetes in the United States, making it the country's seventh leading cause of death. In addition to those who already have type 2 diabetes, it has been estimated that 86 million American adults have prediabetes, a precursor that markedly increases the risk of the development of type 2 diabetes and cardiovascular disease. ${ }^{7}$ Indeed, in the Diabetes Prevention Program study, after 4 years of follow-up, 36\% of participants with prediabetes who were randomized to placebo acquired type 2 diabetes. ${ }^{8}$ Undoubtedly, the alarming increase in overweight and obesity has played a pivotal role in the rise of prediabetes and type 2 diabetes.

Although obesity and aging are shared risk factors for both OSA and type 2 diabetes, there is growing evidence that the relationship between the two conditions is independent of obesity.
This review explores the role of OSA in the pathogenesis of type 2 diabetes and glucose metabolism dysregulation as well as the impact of treating OSA on glucose metabolism. The association between OSA and complications of type 2 diabetes as well as gestational diabetes are also discussed in e-Appendix 1.

\section{Pathophysiology}

Intermittent hypoxemia and sleep fragmentation are cardinal features of OSA and are likely in the causal pathway leading to metabolic dysfunction. Several prospective cross-sectional studies have demonstrated an independent association between the severity of OSA and insulin resistance in individuals without type 2 diabetes. $^{9-12}$ Short-term, laboratory-based experiments in healthy human subjects have demonstrated that sleep restriction, sleep fragmentation, and intermittent hypoxemia can lead to glucose metabolism dysregulation (Fig 1). ${ }^{13-23}$ In healthy volunteers, exposure to 5 hours of intermittent hypoxia during wakefulness, inducing an average of 24 desaturation events/h, led to a $17 \%$ reduction in insulin sensitivity without a simultaneous increase in insulin secretion. ${ }^{24}$ In another experiment, however, exposure to 3 hours of intermittent hypoxia (leading to 25 desaturations/h) resulted in an increase in plasma glucose levels without changes in insulin secretion. ${ }^{24}$ Therefore, there may be a threshold regarding the intensity of hypoxemia or

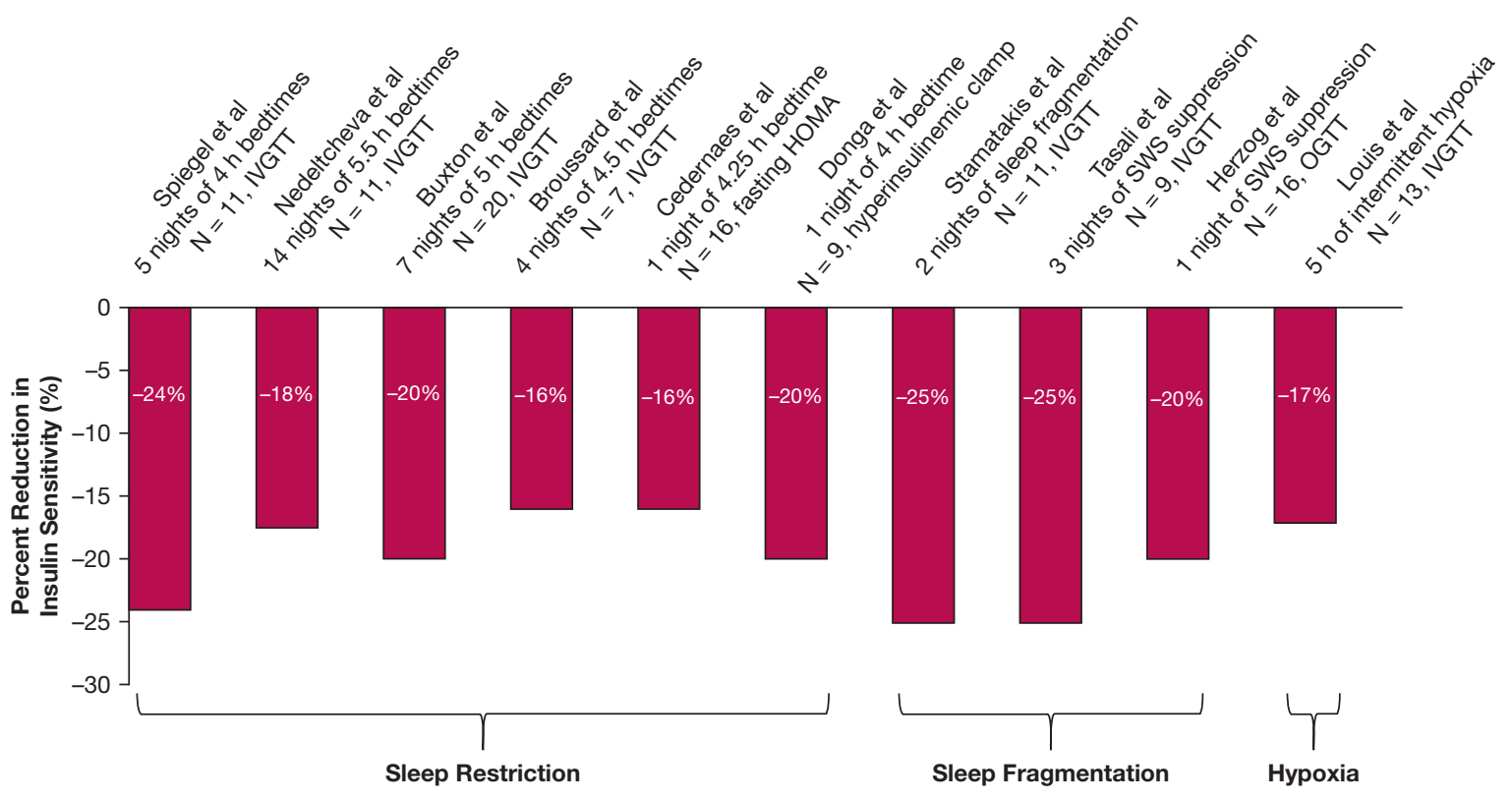

Figure 1 - Laboratory-based experiments assessing changes in insulin sensitivity following sleep manipulations in healthy human subjects. HOMA= homeostasis model assessment; IVGTT= intravenous glucose tolerance test, OGTT= oral glucose tolerance test; SWS = slow wave sleep. Modified with permission from Reutrakul and Van Cauter. ${ }^{23}$ 
duration of exposure that may lead to an adverse impact on insulin sensitivity. ${ }^{25}$ The role of sleep fragmentation on glucose metabolism has been demonstrated in multiple human experiments. Using acoustic stimuli to suppress non-rapid eye movement (REM) slow-wave sleep $^{20-21}$ or to fragment non-REM sleep ${ }^{19}$ reduces insulin sensitivity by $20 \%$ to $25 \%$.

Although the exact pathophysiological and causal links between OSA and glucose metabolism dysregulation are not fully understood, multiple mechanistic pathways are likely to be causally involved. Figure 2 illustrates several of these pathways. Although an in-depth review of all potential causal pathways is beyond the scope of this review, we discuss a few mechanistic pathways.

Direct recordings of muscle sympathetic nerve have demonstrated increased sympathetic activity in patients with OSA. ${ }^{26,27}$ This sympathoexcitation persists during the daytime in untreated patients with OSA and is significantly reduced by effective CPAP therapy. ${ }^{28}$ Most endocrine organs releasing hormones involved in glucose regulation are inhibited by elevations of sympathetic tone. Well-documented examples relevant to metabolic risk are pancreatic insulin secretion, hepatic glucose production, and adipocyte regulation of energy balance. ${ }^{29-31}$ In addition, peptidergic factors originating from the intestine (glucagon-like peptide- 1 and glucosedependent insulinotropic polypeptide) augment the insulin response induced by nutrients. The secretion of these incretin hormones is intimately linked to autonomic nervous system activity. ${ }^{32-34}$ Thus, the sympathetic hyperactivity and parasympathetic withdrawal associated with OSA are likely mediators of its adverse effects on glucose tolerance. An additional assessment of systemic sympathetic nervous system activity is measurement of norepinephrine levels, a wellknown counterregulatory hormone, in bodily fluids. Several studies, including a study in patients with prediabetes, ${ }^{35}$ have shown that treatment of OSA with CPAP decreases norepinephrine levels in plasma as well as in urine. ${ }^{36-38}$ To provide definitive evidence that nocturnal CPAP therapy decreases circulating levels of norepinephrine in patients with type 2 diabetes and OSA, Mokhlesi et $\mathrm{al}^{39}$ performed a proof of concept laboratory-based study using 24-hour blood sampling after 1 week of CPAP therapy during the entire sleep period. This study confirmed a significant reduction in daytime and nighttime plasma norepinephrine levels

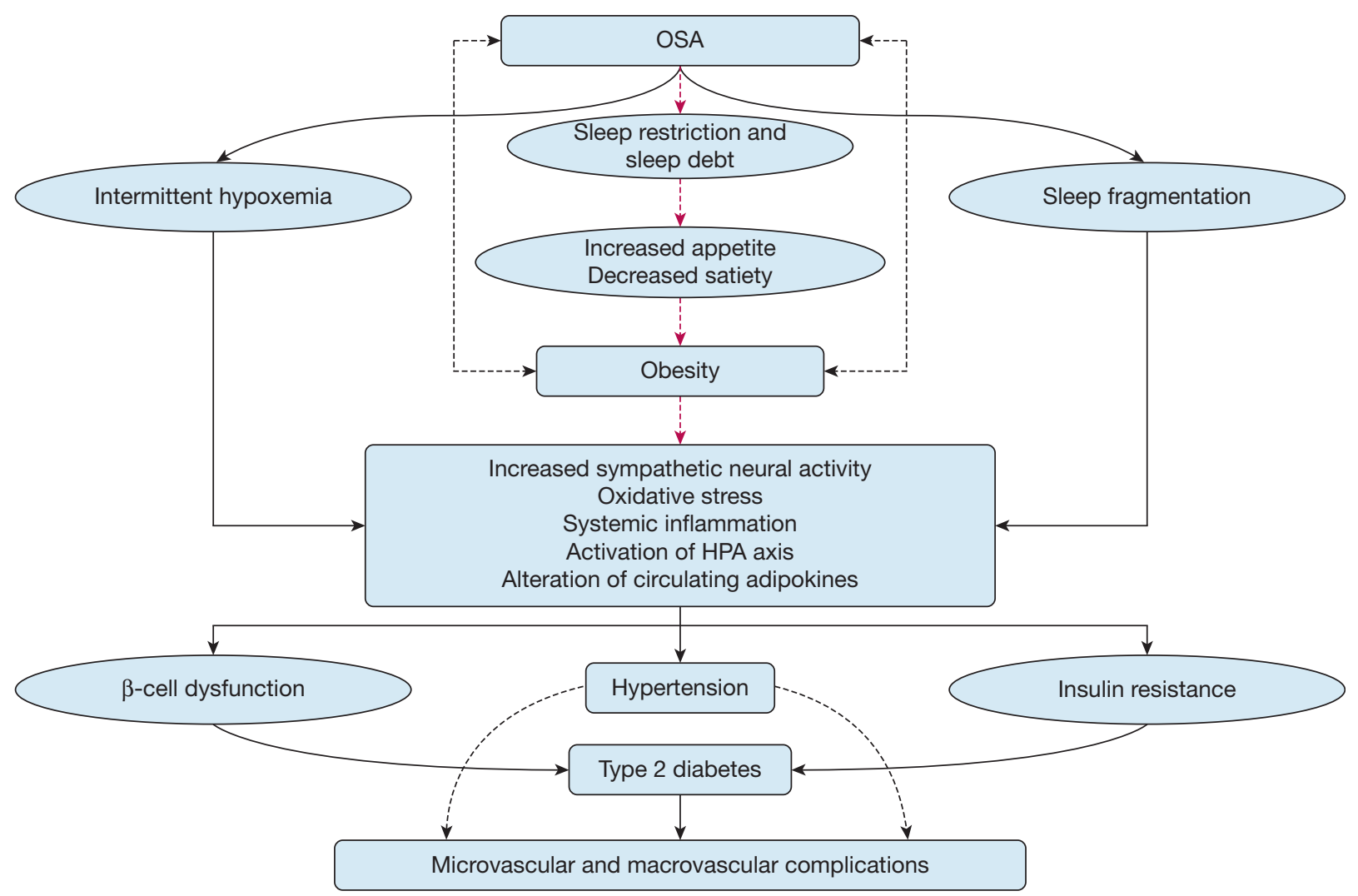

Figure 2 - Mechanistic pathways linking OSA to diabetes. HPA = hypothalamic-pituitary-adrenal. 
without any significant change in 24-hour profiles of plasma cortisol and growth hormone levels. However, the exact role of counterregulatory hormones (ie, cortisol, growth hormone, and glucagon) and the hypothalamic-pituitary-adrenal axis in OSA requires further investigation.

Rodent studies have demonstrated $\beta$-cell dysfunction or $\beta$-cell death after exposure to intermittent hypoxia. ${ }^{40-42}$ Of note, cessation of intermittent hypoxia only partially reverses glucose homeostasis in a rodent model, suggesting that some metabolic derangements, such as $\beta$-cell dysfunction, may not fully recover even after intermittent hypoxia is no longer present. ${ }^{43}$

\section{Role of OSA During REM Sleep}

In a prospective study of 115 subjects with type 2 diabetes, the apnea-hypopnea index (AHI) during REM sleep was independently associated with increasing levels of hemoglobin Alc (HbAlc). In contrast, non-REM AHI was not associated with HbAlc levels. ${ }^{44}$ Consistent with the notion that OSA during REM sleep is metabolically more toxic than non-REM OSA, a recent analysis of the Sleep Heart Health Study demonstrated that OSA in REM sleep was independently associated with insulin resistance after controlling for OSA in nonREM sleep. ${ }^{45}$ Two studies performed continuous interstitial glucose monitoring simultaneous with polysomnography. ${ }^{46,47}$ One study included 13 obese patients with type 2 diabetes and severe OSA and compared them with 13 obese patients with type 2 diabetes without OSA. The mean glucose level was $38 \%$ higher during REM sleep in those with OSA. ${ }^{46}$ The second study included 11 subjects with diabetes. They found that in the absence of OSA, REM sleep leads to a larger decline in interstitial glucose concentration than does non-REM sleep, likely due to an increase in cerebral glucose utilization during REM sleep. OSA during REM sleep, however, abolished the expected decline in interstitial glucose concentration. In contrast, OSA during non-REM sleep had no impact on interstitial glucose concentrations. ${ }^{47}$ Taken together, the evidence suggests that OSA during REM sleep may be adversely associated with glucose metabolism in patients with type 2 diabetes. This may have important therapeutic implications regarding the duration of nightly CPAP use. In healthy adult humans, REM sleep accounts for approximately $20 \%$ of total sleep time and it is mostly concentrated in the second half of the sleep period. Using CPAP for 3 or 4 hours from the time lights are turned off will cover only $25 \%$ or $40 \%$ of REM sleep, respectively, and will leave most obstructive events during REM sleep untreated. In contrast, 7 hours of CPAP use would treat $87 \%$ of REM sleep. ${ }^{44}$

\section{Bidirectional Relationship Between Sleep- Disordered Breathing and Diabetes}

The question of bidirectional association and reverse causality between sleep-disordered breathing and type 2 diabetes is an important one, particularly given the confounding effects of aging and obesity. Further research is needed to fully elucidate whether longstanding poorly controlled diabetes can worsen obstructive and central sleep apnea as well as nocturnal hypoxemia by adversely impacting central control of respiration or upper airway neural reflexes that promote airway patency. ${ }^{48-52}$ In support of reverse causality are studies in younger or nonobese patients with type 1 diabetes having a high prevalence of OSA. ${ }^{53-56}$ Another line of evidence supporting reverse causality comes from 30 patients with type 2 diabetes who were hospitalized for intensification of glycemic control. After 5 days, the nocturnal glycemic profile improved significantly (202 \pm $65 \mathrm{mg} / \mathrm{dL}$ vs $130 \pm 38 \mathrm{mg} / \mathrm{dL} ; P=.005)$. This was accompanied by a $32 \%$ reduction in the $4 \%$ oxygen desaturation index. Importantly, the patients did not experience any change in body weight or neck circumference and self-reported sleep duration remained unchanged. ${ }^{57}$

\section{Epidemiology}

\section{OSA as a Novel Risk Factor for the Development of Type 2 Diabetes}

Longitudinal cohort studies have demonstrated a significant association between OSA and incident type 2 diabetes. To date, a total of 10 studies from various geographic regions around the globe, with a follow-up duration between 2.7 and 16 years, have explored such an association (Table 1). ${ }^{58-67}$ Nine of these studies objectively assessed OSA at baseline, ${ }^{59-67}$ and one performed OSA assessment at the last visit. ${ }^{58}$ After adjusting for multiple confounders known to be associated with type 2 diabetes, nine studies found a significant association between OSA and incident diabetes. ${ }^{58-66}$ Of note, in some of these studies, the association was apparent only for those with moderate or severe OSA. ${ }^{58-62}$ A meta-analysis was previously performed on eight of these studies, ${ }^{68}$ and we performed an updated analysis adding a recent report from the Sleep Heart Health Study. ${ }^{62}$ Our meta-analysis includes a total of 64,101 participants and reveals that OSA is 
TABLE 1 ] Prospective Cohort Studies on the Relationship Between OSA and Incident Type 2 Diabetes

\begin{tabular}{|c|c|c|c|c|c|c|c|c|}
\hline Study/Year & No. & Setting & $\begin{array}{l}\text { Mean Age } \\
\text { (y) }\end{array}$ & $\begin{array}{l}\text { Mean BMI } \\
\left(\mathrm{kg} / \mathrm{m}^{2}\right)\end{array}$ & $\begin{array}{l}\text { Male Sex } \\
(\%)\end{array}$ & Sleep Assessment & $\begin{array}{l}\text { Follow-up } \\
\text { (y) }\end{array}$ & Results \\
\hline $\begin{array}{l}\text { Reichmuth } \\
\text { et } \mathrm{al}^{67} / 2005\end{array}$ & 1,387 & USA & 49.0 & 28.9 & 56.0 & $\begin{array}{l}\mathrm{AHI} \geq 5 \text { by } \\
\text { polysomnography }\end{array}$ & 4 & $\begin{array}{l}\text { No association between OSA and incident } \\
\text { diabetes }\end{array}$ \\
\hline $\begin{array}{l}\text { Botros } \\
\text { et } \mathrm{al}^{63} / 2009\end{array}$ & 544 & USA & 61.5 & 33.2 & 93.4 & $\begin{array}{l}\mathrm{AHI} \geq 8 \text { by } \\
\text { polysomnography }\end{array}$ & 2.7 & $\begin{array}{l}\text { OSA was associated with diabetes; HR, } \\
1.43(95 \% \mathrm{CI}, 1.10-1.86)\end{array}$ \\
\hline $\begin{array}{l}\text { Marshall } \\
\text { et } \mathrm{al}^{60} / 2009\end{array}$ & 295 & Australia & 53.1 & 26.6 & 41.3 & $\begin{array}{l}\text { RDI } \geq 5 \text { from a 4-channel } \\
\text { home monitoring device } \\
\text { (heart rate, oxygen } \\
\text { saturation, snoring, and } \\
\text { body position) }\end{array}$ & 4 & $\begin{array}{l}\text { Moderate to severe OSA (RDI } \geq 15) \text { was } \\
\text { associated with diabetes, OR, } 13.45 \\
(95 \% \mathrm{CI}, 1.59-114.11)\end{array}$ \\
\hline Celen et $\mathrm{al}^{65} / 2010$ & 168 & Sweden & 48.2 & 26.6 & 81.6 & $\begin{array}{l}4 \% \text { ODI } \geq 30 \text { events/night } \\
\text { using nocturnal oximetry, } \\
\text { nasal and oral airflow, } \\
\text { respiratory motion, and } \\
\text { body movement }\end{array}$ & 16 & $\begin{array}{l}\text { OSA was associated with diabetes in } \\
\text { women-OR, } 11.78 \text { ( } 95 \% \text { CI, 1.14- } \\
121.7) \text {-but not in men }\end{array}$ \\
\hline $\begin{array}{l}\text { Muraki } \\
\text { et } \mathrm{al}^{61} / 2010\end{array}$ & 4,606 & Japan & 57.6 & 23.5 & 34.7 & $\begin{array}{l}3 \% \text { ODI } \geq 5 \text { events/h using } \\
\text { pulse oximetry }\end{array}$ & 3 & $\begin{array}{l}\text { Moderate OSA (ODI } \geq 15) \text { was associated } \\
\text { with diabetes; HR, } 1.69 \text { ( } 95 \% \text { CI, 1.04- } \\
2.76 \text { ) }\end{array}$ \\
\hline $\begin{array}{l}\text { Lindberg } \\
\text { et } \mathrm{al}^{66} / 2012\end{array}$ & 141 & Sweden & 57.5 & 26.9 & 100.0 & $\begin{array}{l}\text { ODI }>5 \text { by } \\
\text { polysomnography }\end{array}$ & 11.3 & $\begin{array}{l}\text { ODI > } 5 \text { was associated with diabetes; OR, } \\
4.4(95 \% \mathrm{CI}, 1.1-18.1)\end{array}$ \\
\hline $\begin{array}{l}\text { Boyko } \\
\text { et } \mathrm{al}^{64} / 2013\end{array}$ & 47,093 & USA & 36.7 & 26.3 & 25.3 & $\begin{array}{l}\text { Report of a physician } \\
\text { diagnosis of OSA }\end{array}$ & 6 & $\begin{array}{l}\text { OSA was associated with diabetes; OR, } \\
1.78(95 \% \text { CI, } 1.39-2.28)\end{array}$ \\
\hline $\begin{array}{l}\text { Kendzerska } \\
\text { et } \mathrm{al}^{59} / 2014\end{array}$ & 8,678 & Canada & 48.0 & 28.4 & 62.0 & $\begin{array}{l}\mathrm{AHI} \geq 5 \text { by } \\
\text { polysomnography }\end{array}$ & 5.6 & $\begin{array}{l}\text { AHI }>30 \text { was associated with diabetes; } \\
\quad H R, 1.31(95 \% \mathrm{CI}, 1.07-1.61)\end{array}$ \\
\hline $\begin{array}{l}\text { Appleton } \\
\text { et } \mathrm{al}^{58} / 2015\end{array}$ & 736 & Australia & 59.7 & 28.4 & 100 & $\begin{array}{l}\text { 8-channel in-home } \\
\text { unattended } \\
\text { polysomnography, } \\
\text { measured at the last } \\
\text { follow-up }\end{array}$ & 4.7 & $\begin{array}{l}\text { Severe OSA }(\mathrm{AHI} \geq 30) \text { was associated with } \\
\text { diabetes; OR, } 2.6(95 \% \mathrm{CI}, 1.1-6.1) \\
\text { ODI } \geq 16 \text { was associated with diabetes; OR, } \\
1.85(95 \% \mathrm{CI}, 1.06-3.21)\end{array}$ \\
\hline $\begin{array}{l}\text { Nagayoshi } \\
\text { et } \mathrm{al}^{62} / 2016\end{array}$ & 1,453 & USA & 62.5 & 28.3 & 46.3 & $\begin{array}{l}\mathrm{AHI} \geq 5 \text { by unattended in- } \\
\text { home polysomnography }\end{array}$ & 12.8 & $\begin{array}{l}\text { Severe OSA (AHI } \geq 30 \text { ) was associated } \\
\text { with diabetes; HR } 1.71 \text { ( } 95 \% \text { CI, } 1.08- \\
2.71) \text {, whereas mild and moderate OSA } \\
\text { were not associated with diabetes } \\
\text { Results were similar for those with } \\
\text { BMI } \geq 30 \mathrm{~kg} / \mathrm{m}^{2}\end{array}$ \\
\hline
\end{tabular}

$\mathrm{AHI}=$ apnea hypopnea index; $\mathrm{HR}=$ hazard ratio; $\mathrm{ODI}=$ oxygen desaturation index; RDI = respiratory disturbance index. 
associated with incident diabetes, with an unadjusted pooled relative risk of 1.62 (95\% CI, 1.45-1.80) and an adjusted pooled relative risk of 1.35 (95\% CI, 1.24-1.47) (Fig 3). To put in perspective, it is useful to compare the risk conferred by OSA with other traditional risk factors for type 2 diabetes. Indeed, the effect size of OSA is larger than being physically inactive (adjusted relative risk of 1.20) but smaller than having a family history of diabetes (adjusted relative risk of 2.33). ${ }^{68}$ Finally, a few prospective studies have also shown that self-reported snoring or observed apneas are associated with incident type 2 diabetes. ${ }^{69-71}$

A

\section{Pooled crude relative risk}

$\%$

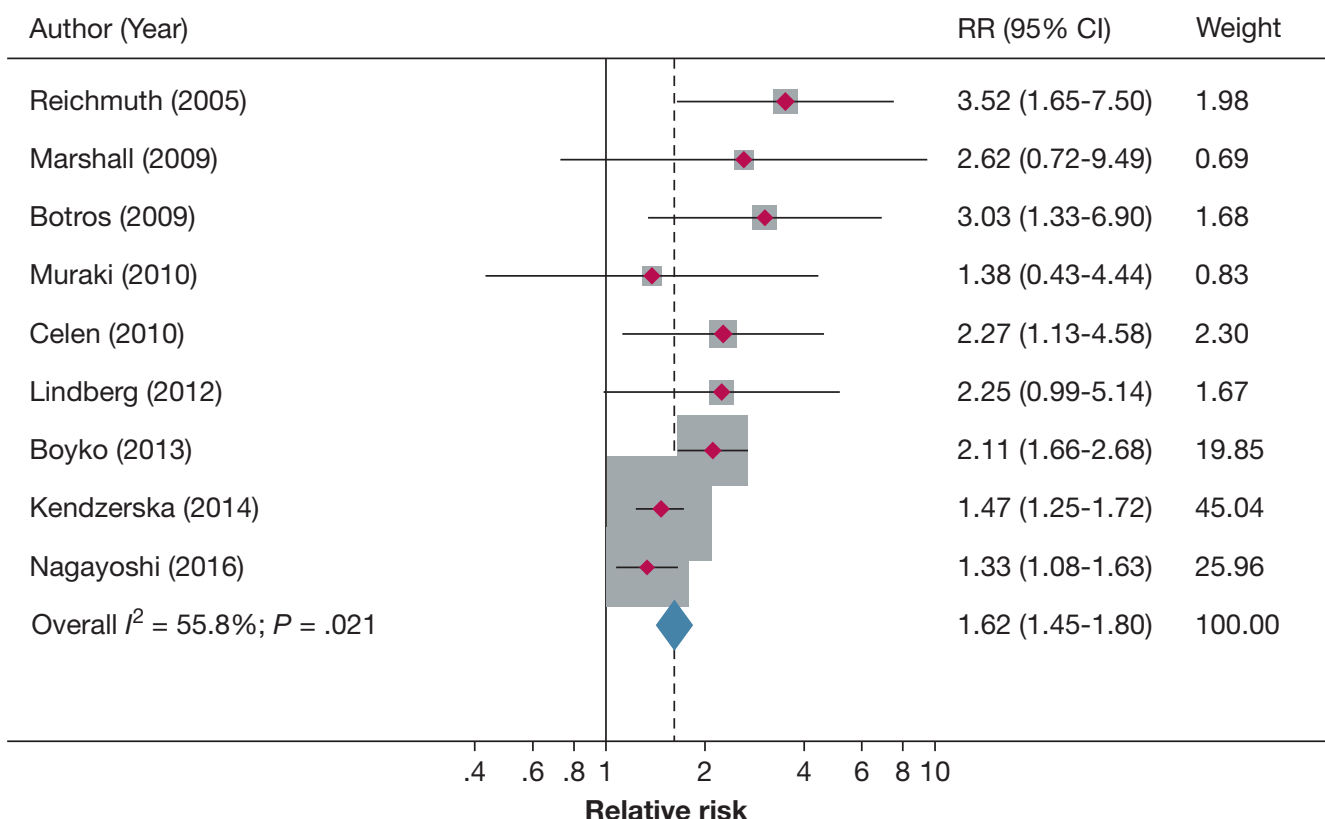

B

Pooled adjusted relative risk $\%$

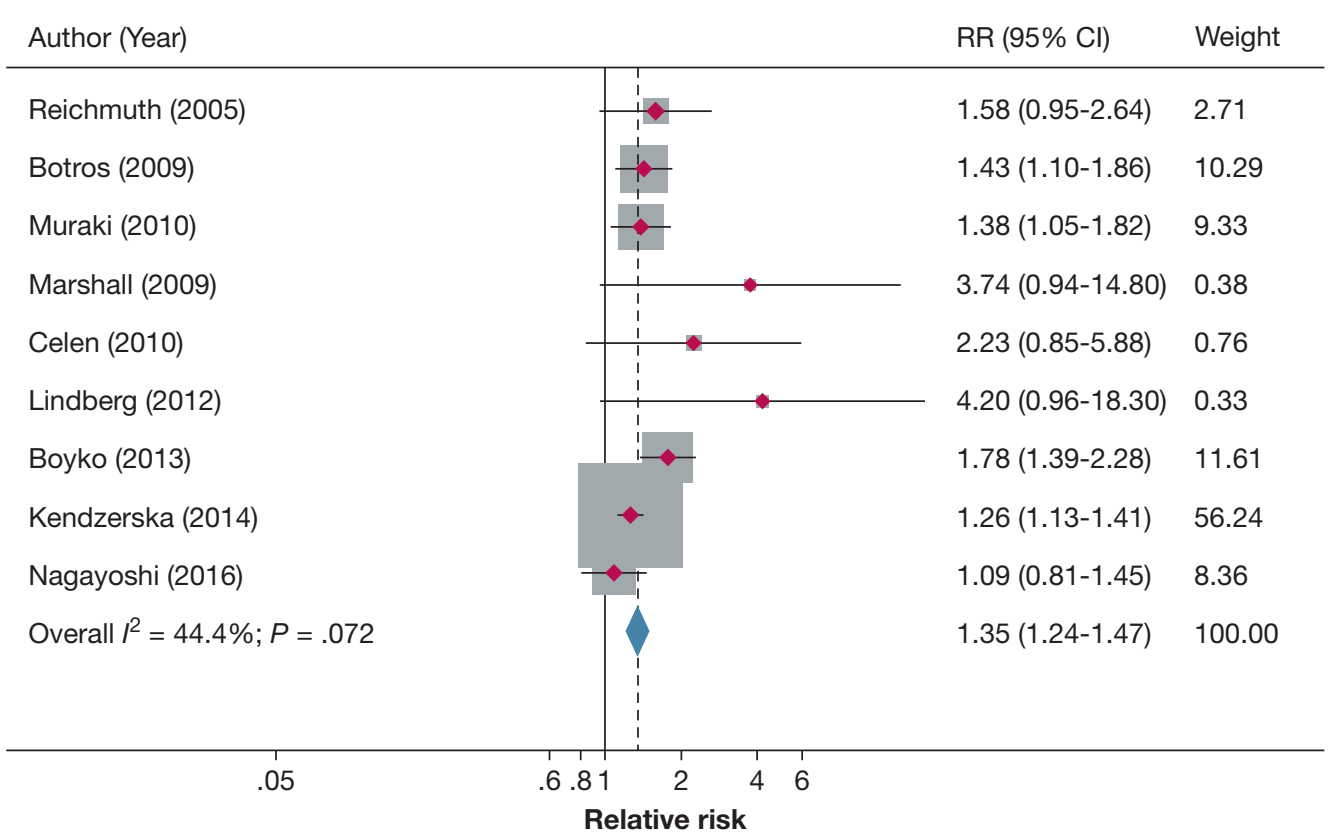

Figure 3 - Relative risk of incident diabetes from prospective cohort studies in those with OSA compared with those without OSA. A, Unadjusted pooled relative risk. $B$, Adjusted pooled relative risk. 


\section{Prevalence of OSA in Patients With Type 2 Diabetes}

Multiple independent studies have explored the prevalence of OSA in patients with type 2 diabetes. As illustrated in Figure 4, the prevalence of OSA is alarmingly elevated in both community-based and clinic-based cohorts that have included participants from diverse ethnic backgrounds with type 2 diabetes. ${ }^{44,48,72-81}$ OSA, however, remains undiagnosed in the majority of patients with type 2 diabetes being managed by primary care providers. ${ }^{82}$

\section{Prevalence of Type 2 Diabetes in Patients With OSA}

Among individuals with OSA, the prevalence of type 2 diabetes has been estimated to be $15 \%$ to $30 \%$, with higher prevalence in those with severe OSA. ${ }^{60,67,83,84}$ However, adjustment for BMI and other confounders attenuates the findings in some studies. ${ }^{60,83,84}$

\section{Untreated OSA Is Associated With Worse Glycemic Control in Type 2 Diabetes}

Several studies using in-laboratory polysomnography or respiratory polygraphy to accurately quantify the severity of OSA have reported a robust association between increasing OSA severity and increasing levels of $\mathrm{HbA1c}$ in patients with type 2 diabetes after controlling for multiple potential confounders (Fig 5). ${ }^{44,75,84-86}$
These studies enrolled between 52 and 1,138 participants with type 2 diabetes. When comparing severe OSA with no or mild OSA, the adjusted increase in $\mathrm{HbA1c}$ ranged from $0.5 \%$ to $3.7 \%$. Two studies with smaller sample sizes reported the largest effect size, likely due to statistical overadjustment. ${ }^{75,85}$ In a study of 162 Chinese patients with type 2 diabetes and OSA, there was no independent association between $\mathrm{AHI}$ and $\mathrm{HbA1c}$ levels. However, in this study, the adjusted HbAlc was not compared among the various OSA severity categories. ${ }^{76}$ Therefore, based on studies with larger sample sizes, it is likely that when compared with no or mild OSA, severe OSA is associated with an adjusted increase in $\mathrm{HbAlc}$ levels of $0.5 \%$ to $0.8 \%{ }^{44,84,86}$

\section{Screening for OSA in Patients With Type 2 Diabetes}

Given the high prevalence of OSA in patients with diabetes, there is increasing awareness of OSA among diabetes societies. In 2008, the International Diabetes Federation's Task Force on Epidemiology and Prevention strongly recommended that health professionals caring for patients with either type 2 diabetes or sleepdisordered breathing consider screening a patient presenting with one condition for the other. ${ }^{87}$ In 2017, the American Diabetes Association recognized OSA as an important comorbidity, as well as the benefits of its

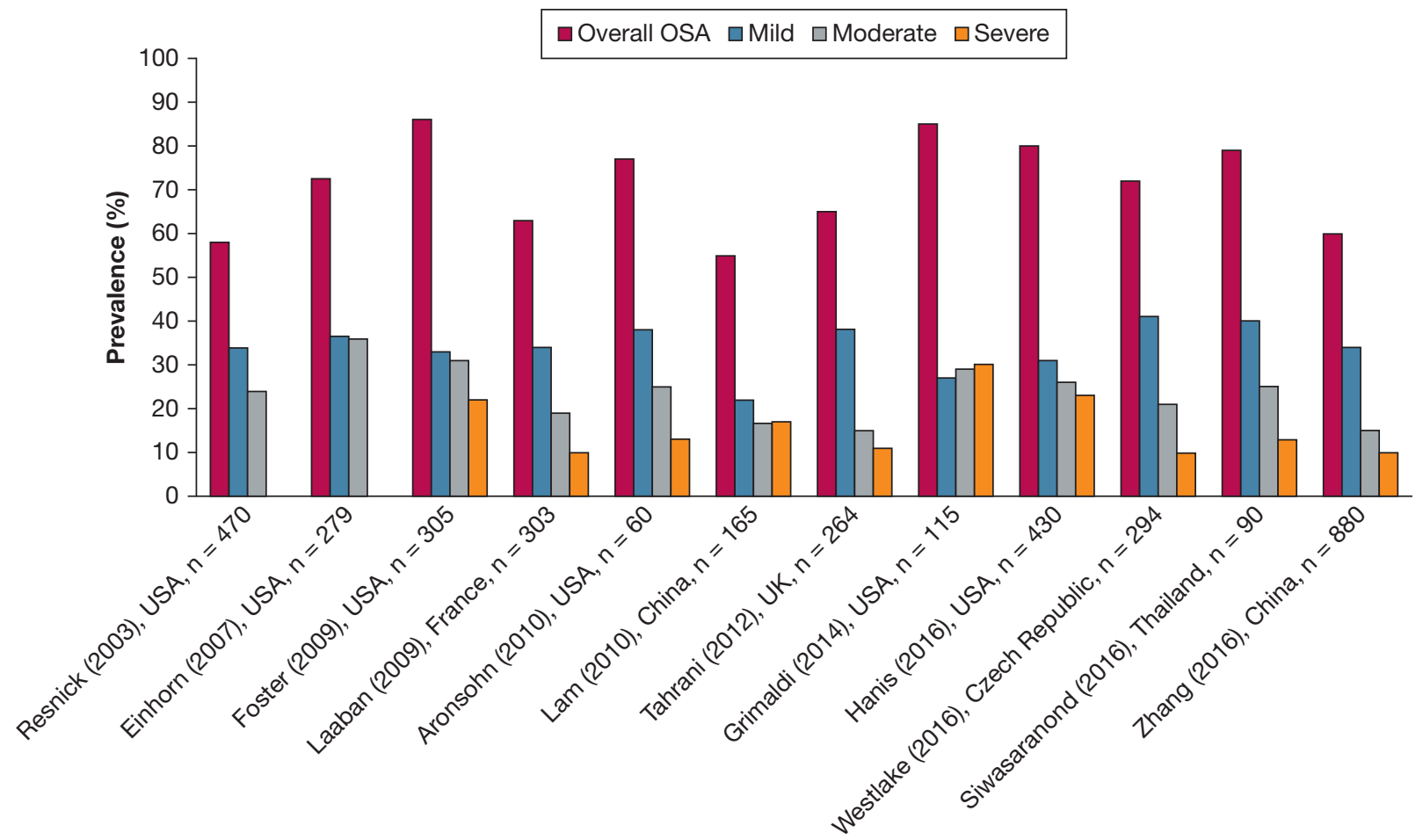

Figure 4 - OSA prevalence in studies of patients with type 2 diabetes. In the study by Resnick et al ${ }^{48}$ and Einhorn et al ${ }^{72}$, the moderate OSA column includes moderate and severe OSA. 


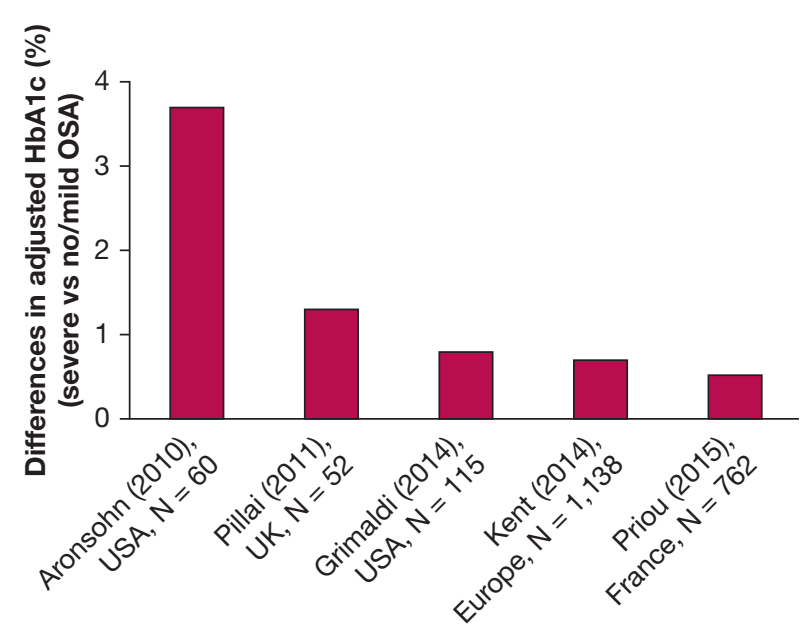

Figure 5 - Prospective studies examining the independent association between OSA severity and glycemic control assessed by HbAlc in type 2 diabetes. HbA1c has been adjusted for important confounders and represents the difference between severe OSA and no/mild OSA. In the study by Grimaldi et al, the highest quartile of the apnea-hypopnea index (AHI) during rapid eye movement (REM) sleep was compared with the lowest quartile or REM AHI. The mean total AHI in the highest quartile of REM AHI was 47 events/h. In contrast, the mean total AHI in the lowest quartile of REM AHI was 9 events/h. HbA1c = hemoglobin A1c.

treatment on BP and quality of life in patients with type 2 diabetes. ${ }^{88}$ However, given such a high prevalence (ie, high pretest probability), it remains unclear whether questionnaires used for OSA screening would provide sufficient sensitivity and specificity in patients with type 2 diabetes. Thus far, only one study has compared the Berlin questionnaire and the STOP and STOP-Bang questionnaires in 294 patients with type 2 diabetes with home sleep monitoring (type IV sleep monitor). ${ }^{79}$ This study revealed that all the questionnaires had a similar, but rather low, sensitivity and specificity. Therefore, given the high prevalence of OSA in patients with type 2 diabetes and the suboptimal performance of screening questionnaires, clinicians should consider exploring the diagnosis of OSA using home sleep apnea monitoring devices if clinically appropriate.

\section{Treatment}

CPAP remains the most efficacious treatment and continues to be considered the gold standard for treating patients with moderate to severe OSA. Randomized controlled trials examining the effect of CPAP on glucose metabolism are summarized in Tables $2^{35,89-99}$ and 3. e-Table 1 summarizes ongoing randomized controlled trials in patients with type 2 diabetes and sleep apnea.

\section{CPAP in Patients Without Diabetes}

Ten studies (a total of 512 participants with a range of 13 to 136 participants in each study) were conducted in participants without diabetes (Table 2). The duration of follow-up ranged from 1 to 24 weeks, and most studies achieved an average nightly CPAP use of $\geq 4$ hours. Glucose metabolism and insulin sensitivity were assessed by different methods. Seven of these studies found no significant differences in markers of glucose metabolism between the CPAP and control groups, ${ }^{89-95}$ whereas one found significant improvement in insulin sensitivity ${ }^{96}$ and one found an improvement in glucose metabolism as assessed by a 75-g oral glucose tolerance test (OGTT) ${ }^{97}$ The largest study by Chirinos et al ${ }^{98}$ $(\mathrm{N}=136)$ randomized participants to CPAP, weight loss, or combined intervention (CPAP plus weight loss) for 24 weeks. ${ }^{98}$ The weight loss and combined intervention groups lost 6.8 and $7.0 \mathrm{~kg}$, respectively. Insulin sensitivity, as assessed by an IV glucose tolerance test (IVGTT), improved in the weight loss and combined intervention groups but not in the CPAP alone group. Weight loss provided an incremental improvement in insulin sensitivity when combined with CPAP.

\section{CPAP in Patients With Prediabetes}

Two studies specifically tested the effects of CPAP on glucose metabolism in people with prediabetes (Table 2). Pamidi et a ${ }^{35}$ compared 2 weeks of nightly CPAP use ( 8 hours each night under direct supervision in the sleep laboratory) with oral placebo in 39 participants with prediabetes. ${ }^{35}$ The CPAP group had a significant improvement in insulin sensitivity and overall glucose response following OGTT compared with the control group. In another study, 8 weeks of home CPAP use (average mean adherence of $4.8 \mathrm{~h} /$ night) improved insulin sensitivity and 2-hour insulin levels only in those with severe OSA. ${ }^{99}$

These conflicting results in participants without diabetes could in part be due to different baseline glycemic status, various degrees of CPAP adherence, and different methods used to assess glucose metabolism. A metaanalysis that included four of these studies also found no differences in fasting glucose levels or homeostatic model assessment (HOMA), although there was a significant reduction in fasting insulin levels. ${ }^{100}$ Given that two well-designed small studies in individuals with prediabetes have suggested favorable effects of OSA resolution on glucose metabolism, ${ }^{35,99}$ additional longerterm and larger studies are needed to explore if effective treatment of OSA can reduce the risk of developing type 2 diabetes. Moreover, studies should explore the role of various lifestyle interventions, such as weight reduction 
TABLE 2 ] Randomized Controlled Studies Exploring the Effects of CPAP on Glucose Metabolism in Subjects Without Diabetes and Those With Prediabetes

\begin{tabular}{|c|c|c|c|c|c|c|c|}
\hline Studies & No. & Study Design & OSA Definition & Duration & $\begin{array}{l}\text { Adherence } \\
\text { (Hours Per } \\
\text { Night) }\end{array}$ & $\begin{array}{l}\text { Glucose Metabolism } \\
\text { Markers }\end{array}$ & Results \\
\hline \multicolumn{8}{|l|}{ No diabetes } \\
\hline Coughlin et $\mathrm{al}^{89} / 2007$ & $\begin{array}{l}34 \\
17 \text { CPAP/sham } \\
17 \text { sham/CPAP }\end{array}$ & Crossover & $\mathrm{AHI}>15$ & $6 \mathrm{wk}$ & $\begin{array}{l}\text { CPAP, } 3.9 \\
\text { Sham, } 2.6\end{array}$ & $\begin{array}{l}\text { Fasting glucose, } \\
\text { insulin, and } \\
\text { HOMA }\end{array}$ & $\begin{array}{l}\text { No difference in all glucose } \\
\text { parameters }\end{array}$ \\
\hline $\begin{array}{l}\text { Comondore } \\
\text { et } \mathrm{al}^{90} / 2009\end{array}$ & $\begin{array}{l}13 \mathrm{CPAP} / \text { no therapy or } \\
\text { no therapy/CPAP }\end{array}$ & Crossover & $\mathrm{AHI}>15$ & $4 \mathrm{wk}$ & CPAP, 5.5 & $\begin{array}{l}\text { Fasting glucose } \\
\text { and insulin, } \\
\text { HOMA, HbA1c }\end{array}$ & No difference \\
\hline Lam et $\mathrm{al}^{96} / 2010$ & $\begin{array}{l}61 \\
30 \text { CPAP } \\
31 \text { sham }\end{array}$ & Parallel group & $\mathrm{AHI} \geq 15$ & $1 \mathrm{wk}$ & $\begin{array}{l}\text { CPAP, } 6.2 \\
\text { Sham, } 4.5\end{array}$ & $\begin{array}{l}\text { Insulin sensitivity } \\
\text { (from SITT), } \\
\text { fasting glucose, } \\
\text { insulin, and } \\
\text { HOMA }\end{array}$ & $\begin{array}{l}\text { Significant reduction in } \\
\text { insulin sensitivity from } \\
\text { SITT } \\
\text { No differences in other } \\
\text { parameters }\end{array}$ \\
\hline Nguyen et $\mathrm{al}^{91} / 2010$ & $\begin{array}{l}20 \\
10 \text { CPAP } \\
10 \text { sham } \\
\text { (1 subject with } \\
\text { diabetes) }\end{array}$ & Parallel group & $\mathrm{RDI} \geq 15$ & $3 \mathrm{mo}$ & $\begin{array}{l}\text { CPAP, } 5.1 \\
\text { Sham, } 4.9\end{array}$ & Fasting glucose & No difference \\
\hline Kohler et $\mathrm{al}^{92} / 2011$ & $\begin{array}{l}41 \\
20 \text { CPAP ( } 4 \text { with } \\
\text { diabetes) } \\
21 \text { sham ( } 5 \text { with } \\
\text { diabetes) }\end{array}$ & $\begin{array}{l}\text { Parallel group } \\
\text { CPAP } \\
\text { withdrawal } \\
\text { protocol }\end{array}$ & $4 \%$ ODI $>10$ & $2 w k$ & $\begin{array}{l}\text { CPAP, } 6.4 \\
\text { Sham, } 4.7\end{array}$ & $\begin{array}{l}\text { Fasting glucose, } \\
\text { insulin, and } \\
\text { HOMA }\end{array}$ & No difference \\
\hline Hoyos et $\mathrm{al}^{93} / 2012$ & $\begin{array}{l}65 \\
34 \text { CPAP } \\
31 \text { sham }\end{array}$ & Parallel group & $\begin{array}{l}\mathrm{AHI} \geq 20 \text { and } \\
\quad 3 \% \text { ODI } \geq 15\end{array}$ & $12 \mathrm{wk}$ & $\begin{array}{l}\text { CPAP, } 3.6 \\
\text { Sham, } 2.8\end{array}$ & $\begin{array}{l}\text { Insulin sensitivity } \\
\text { (minimal } \\
\text { model), } \\
\text { fasting glucose, } \\
\text { insulin, HOMA, } \\
\text { disposition } \\
\text { index }\end{array}$ & $\begin{array}{l}\text { No differences in intention- } \\
\text { to-treat analysis at } 12 \mathrm{wk} \\
\text { Improvement in insulin } \\
\text { sensitivity noted at } 24 \mathrm{wk} \\
\text { in the nonrandomized } \\
\text { phase when participants } \\
\text { randomized to sham CPAP } \\
\text { were treated with } \\
\text { therapeutic CPAP }\end{array}$ \\
\hline Sivam et $\mathrm{al}^{94} / 2012$ & $\begin{array}{l}27 \\
\text { CPAP/sham or sham/ } \\
\text { CPAP }\end{array}$ & Crossover & $\mathrm{AHI} \geq 25$ & $8 w k$ & $\begin{array}{l}\text { CPAP, } 4.6 \\
\text { Sham, } 3.4\end{array}$ & Fasting glucose & No difference \\
\hline Kritikou et $\mathrm{al}^{95} / 2014$ & $\begin{array}{l}35 \text { CPAP/sham or } \\
\text { sham/CPAP }\end{array}$ & Crossover & $\begin{array}{l}\text { AHI }>10 \text { for } \\
\text { female } \\
\text { persons, }>15 \\
\text { for male } \\
\text { persons }\end{array}$ & $2 \mathrm{mo}$ & $\begin{array}{l}\text { CPAP, } 6.1 \\
\text { Sham, } 5.3\end{array}$ & HOMA & No difference \\
\hline
\end{tabular}


TABLE 2 ] (Continued)

\begin{tabular}{|c|c|c|c|c|c|c|c|}
\hline Studies & No. & Study Design & OSA Definition & Duration & $\begin{array}{c}\text { Adherence } \\
\text { (Hours Per } \\
\text { Night) }\end{array}$ & $\begin{array}{c}\text { Glucose Metabolism } \\
\text { Markers }\end{array}$ & Results \\
\hline Chirinos et $\mathrm{al}^{98} / 2014$ & $\begin{array}{l}136 \\
48 \text { CPAP } \\
42 \text { weight loss } \\
62 \text { CPAP plus weight } \\
\text { loss (combined) }\end{array}$ & Parallel group & $\mathrm{AHI} \geq 15$ & 24 wk & $\begin{array}{l}\text { CPAP, } 4 \\
\text { Combined, } \\
\quad 4\end{array}$ & $\begin{array}{l}\text { Insulin sensitivity } \\
\text { from IVGTT }\end{array}$ & $\begin{array}{l}6.8 \text { and } 7.0 \mathrm{~kg} \text { weight loss in } \\
\text { weight loss and combined } \\
\text { group, respectively } \\
\text { Insulin sensitivity improved } \\
\text { in weight loss and } \\
\text { combined groups but not } \\
\text { with CPAP alone }\end{array}$ \\
\hline Salord et $\mathrm{al}^{97} / 2016$ & $\begin{array}{l}80 \\
42 \text { CPAP } \\
38 \text { lifestyle } \\
\quad \text { adjustment }\end{array}$ & Parallel group & $\mathrm{AHI}>30$ & $12 \mathrm{wk}$ & CPAP, 5.4 & $\begin{array}{l}\text { Fasting and 2-h } \\
\text { glucose after } \\
75-\mathrm{g} \text { OGTT, } \\
\text { HOMA, } \\
\text { glycosylated } \\
\text { hemoglobin }\end{array}$ & $\begin{array}{l}\text { Improvement in glucose } \\
\text { tolerance from 75-g OGTT } \\
\text { No differences in fasting } \\
\text { glucose, HOMA, or } \\
\text { glycosylated hemoglobin }\end{array}$ \\
\hline \multicolumn{8}{|l|}{ Prediabetes } \\
\hline Weinstock et al ${ }^{99} / 2012$ & $\begin{array}{l}50 \text { participants with } \\
\text { impaired glucose } \\
\text { tolerance }(2-\mathrm{h} \\
\text { OGTT } \geq 140 \mathrm{mg} / \mathrm{dL}) \\
25 \mathrm{CPAP} / \mathrm{sham} \\
25 \text { sham/CPAP }\end{array}$ & Crossover & $\mathrm{AHI}>15$ & $\begin{array}{l}\text { 8-wk } \\
\text { crossover } \\
\text { design }\end{array}$ & $\begin{array}{l}\text { CPAP, } 4.8 \\
\text { Sham, } 3.4\end{array}$ & $\begin{array}{l}\text { Fasting and } 2-\mathrm{h} \\
\text { glucose, fasting, } \\
\text { and } 2-\mathrm{h} \text { insulin, } \\
\text { insulin } \\
\text { sensitivity (Gutt } \\
\text { index), HOMA }\end{array}$ & $\begin{array}{l}\text { No difference, no reversal of } \\
\text { IGT } \\
\text { Insulin sensitivity and } 2-\mathrm{h} \\
\text { insulin level improved only } \\
\text { in severe OSA }(\mathrm{AHI} \geq 30)\end{array}$ \\
\hline Pamidi et $\mathrm{al}^{35} / 2015$ & $\begin{array}{l}39 \text { with prediabetes } \\
\text { (fasting plasma } \\
\text { glucose } 100-125 \text { or } \\
2 \text {-h glucose } 140- \\
199 \mathrm{mg} / \mathrm{dL} \text {, or both } \\
26 \text { CPAP } \\
13 \text { oral placebo }\end{array}$ & Parallel group & $\mathrm{AHI} \geq 5$ & $\begin{array}{l}2 \text { wk, in } \\
\text { laboratory } \\
\text { proof of } \\
\text { concept } \\
\text { Parallel } \\
\text { group } \\
\text { design }\end{array}$ & CPAP, 8 & $\begin{array}{l}\text { Fasting and 2-h } \\
\text { glucose and } \\
\text { insulin, insulin, } \\
\text { AUC glucose and } \\
\text { insulin (OGTT) } \\
\text { Insulin sensitivity } \\
\text { IVGTT) }\end{array}$ & $\begin{array}{l}\text { Improvement in insulin } \\
\text { sensitivity and AUC } \\
\text { glucose, } \\
\text { no differences in other } \\
\text { parameters }\end{array}$ \\
\hline
\end{tabular}

$\mathrm{AUC}=$ area under the curve; $\mathrm{HbA1c}=$ hemoglobin $\mathrm{A} 1 \mathrm{c} ; \mathrm{HOMA}=$ homeostatic model assessment; IGT = impaired glucose tolerance; IVGTT = IV tolerance test OGT = oral glucose tolerance; SITT = short IV glucose tolerance test. See Table 1 legend for expansion of other abbreviations. 
and physical activity, combined with OSA therapy as a primary prevention strategy for type 2 diabetes. ${ }^{8}$

\section{CPAP in Patients With Type 2 Diabetes}

To date, seven controlled studies, including a total of 498 participants, have specifically explored the effect of CPAP on glycemic control in patients with type 2 diabetes, with a follow-up duration of 1 week to 6 months (Table 3)..$^{38,101-106}$ The participants varied in their baseline glycemic status and diabetes medication use. CPAP use also varied from 2.5 to $7.9 \mathrm{~h} /$ night. Of the four studies with a follow-up duration of 3 to 6 months that measured $\mathrm{HbAlc}$ levels, an indicator of glycemic control in the preceding 90 days, three did not find any significant reduction, ${ }^{38,101,102}$ whereas one study found a significant reduction of $0.4 \%$ after 6 months. ${ }^{104}$ Another study found a similar reduction of $0.4 \%$ in $\mathrm{HbAlc}$ levels only after excluding dropouts and analyzing those whose medications had not changed. ${ }^{106}$ In a proof of concept study, Mokhlesi et $\mathrm{al}^{103}$ assigned 13 patients with OSA and type 2 diabetes to either nightly CPAP $(n=13)$ or sham CPAP $(\mathrm{n}=6)$ for 1 week under nightly supervision in the sleep laboratory to ensure full compliance with the allocated treatment. ${ }^{103}$ Using a 24hour blood sampling technique at 15- to 30-min intervals, the 24-hour mean plasma glucose level decreased significantly more after 1 week of active vs sham CPAP treatment $(-13.7 \pm 3.6 \mathrm{mg} / \mathrm{dL}$ vs $-2.9 \pm$ $1.4 \mathrm{mg} / \mathrm{dL} ; P=.013)$. This decrease in mean plasma glucose was associated with a trend toward lower 24hour mean insulin levels $(-25.8 \pm 16.5 \mathrm{pmol} / \mathrm{L}$ vs $28.4 \pm$ $21.6 \mathrm{pmol} / \mathrm{L} ; P=.071)$. Improvement in glucose levels was most prominent during the overnight period, resulting in lower morning fasting glucose levels. Importantly, the beneficial effect of CPAP was of larger magnitude in participants with poor glycemic control at baseline. If maintained, this degree of reduction in plasma glucose levels would translate to a reduction in the $\mathrm{HbAlc}$ level of $0.4 \%$, an effect size similar to that found in two other studies. ${ }^{104,106}$

Several important points need to be considered when interpreting the results of studies involving patients with type 2 diabetes. A sustained reduction of HbAlc levels by $1 \%$ can translate to a clinically meaningful reduction in microvascular complications. ${ }^{107}$ If effective treatment of OSA across the entire sleep cycle can lead to a reduction in $\mathrm{HbA} 1 \mathrm{c}$ levels of $0.4 \%,{ }^{39,44,103,104,106}$ this would translate to a significant reduction in microvascular complications. Moreover, effective CPAP therapy may have an effect size similar to that achieved by some oral pharmacologic agents. Baseline glycemic characteristics and disease severity in patients in each study may also play a role in the outcomes. In the largest study by Shaw et al ${ }^{101}$, which demonstrated no glycemic benefits with CPAP therapy, the severity of diabetes may have been mild, since the baseline HbA1c level was 7.3\%, and one-half of the patients were not taking any medications for diabetes. In contrast, in the study by Martinez-Ceron et al, ${ }^{104}$ which demonstrated glycemic benefit with CPAP therapy, the baseline HbAlc level was $7.6 \%$, and all subjects were taking oral medications, with $42 \% \%$ requiring insulin. ${ }^{104}$ It is known that the glucose-lowering effect of diabetes medications is greater in patients with a higher baseline HbAlc level. Therefore, similar to pharmacologic agents, it may be that CPAP is more effective in patients with poorer glycemic control at baseline. In addition, other factors such as concomitant medication use (particularly insulin) and a long-standing duration of type 2 diabetes may attenuate the effect of CPAP on glycemic control.

Although the effects of CPAP therapy on overall glycemic control remain contradictory, it is important to entertain other potential benefits of CPAP. A few studies have reported a beneficial effect of CPAP on postprandial/nocturnal glycemia as well as glycemic variability in patients with type 2 diabetes using continuous interstitial glucose monitoring ${ }^{108-110}$ or by frequent venous blood sampling during sleep. ${ }^{39}$ Several studies have demonstrated a significant reduction in blood pressure ${ }^{38,101,106,111,112}$ likely due to a reduction in sympathetic activity. ${ }^{113}$ Decreased inflammatory markers, ${ }^{104}$ reduced sleepiness, ${ }^{102}$ improved quality of life, ${ }^{101}$ and reduced health-care resource use are other favorable effects. ${ }^{111}$ With a rapidly expanding list of diabetes medications that have become available in the last 10 to 15 years, the role of CPAP use may only be adjunctive in improving glycemic control in this patient group.

\section{Impact of Weight Loss in Patients With OSA and Type 2 Diabetes}

Beyond CPAP, weight loss through lifestyle intervention, pharmacotherapy, or bariatric interventions have proved effective in reducing OSA severity and glycemic status in obese patients with type 2 diabetes. In the Sleep AHEAD study, weight reduction from intensive lifestyle modification $(10.8 \mathrm{~kg})$ was associated with an adjusted mean reduction in AHI of 9.7 events/h and a greater reduction in $\mathrm{HbAlc}$ levels compared with standard diabetes support and education 
TABLE 3 ] Clinical Trials Exploring the Effects of CPAP on Glucose Metabolism in Type 2 Diabetes

\begin{tabular}{|c|c|c|c|c|c|c|c|c|}
\hline Studies & No. & $\begin{array}{l}\text { Study } \\
\text { Design }\end{array}$ & OSA Definition & $\begin{array}{l}\text { Baseline Glycemic } \\
\text { Characteristics }\end{array}$ & Duration & $\begin{array}{l}\text { Adherence } \\
\text { (Hours per } \\
\text { Night) }\end{array}$ & $\begin{array}{c}\text { Glucose Metabolism } \\
\text { Markers }\end{array}$ & Results \\
\hline $\begin{array}{l}\text { West } \\
\text { et } \mathrm{al}^{102} / 2007\end{array}$ & $\begin{array}{l}42 \\
20 \text { CPAP } \\
22 \text { sham }\end{array}$ & $\begin{array}{l}\text { Parallel } \\
\text { group }\end{array}$ & $\begin{array}{c}4 \% \text { ODI } \\
>10\end{array}$ & $\begin{array}{l}\text { CPAP, HbA1c } 8.5 \% \\
\text { Sham, HbA1c } 8.4 \%\end{array}$ & $3 \mathrm{mo}$ & $\begin{array}{l}\text { CPAP, } 3.3 \\
\text { Sham, } 3.5\end{array}$ & $\begin{array}{l}\text { HbA1c, } \\
\text { insulin sensitivity by } \\
\text { HOMA and } \\
\text { euglycemic } \\
\text { hyperinsulinemic } \\
\text { clamp }\end{array}$ & $\begin{array}{l}\text { No difference: } \\
\text { improved sleepiness }\end{array}$ \\
\hline $\begin{array}{l}\text { Myhill } \\
\text { et } \mathrm{al}^{38} / 2012\end{array}$ & $\begin{array}{l}44 \\
\text { Early }(1 \mathrm{wk}) \\
\quad \text { or late }(1-2 \\
\text { mo) CPAP } \\
\text { start }\end{array}$ & $\begin{array}{l}\text { Parallel } \\
\text { group }\end{array}$ & $\mathrm{AHI}>15$ & $\begin{array}{l}\text { HbA1c, } \\
6.9 \%(9.3 \% \text { diet } \\
\text { controlled, } \\
62.8 \% \text { OHA, } \\
27.9 \% \text { insulin and } \\
\text { OHA) }\end{array}$ & $3 \mathrm{mo}$ & 5.4 & HbA1c & $\begin{array}{l}\text { No difference: } \\
\text { significant reduction in systolic } \\
\text { and diastolic BP ( } 9 \text { and } \\
7 \mathrm{~mm} \mathrm{Hg} \text {, respectively) }\end{array}$ \\
\hline $\begin{array}{l}\text { Lam } \\
\text { et } \mathrm{al}^{106} / 2017\end{array}$ & $\begin{array}{l}64 \\
32 \text { CPAP } \\
32 \text { no } \\
\text { treatment }\end{array}$ & $\begin{array}{l}\text { Parallel } \\
\text { group }\end{array}$ & $\mathrm{AHI} \geq 15$ & $\begin{array}{l}\text { CPAP: HbA1c, } \\
8.1 \%(78 \% \text { OHA, } \\
22 \% \text { OHA and } \\
\text { insulin) } \\
\text { No treatment: } \\
\text { HbA1c, } \\
8.4 \%(62 \% \text { OHA, } \\
38 \% \text { OHA and } \\
\text { insulin) }\end{array}$ & $3 \mathrm{mo}$ & CPAP, 2.5 & $\begin{array}{l}\text { HbA1c, fasting } \\
\text { glucose }\end{array}$ & $\begin{array}{l}\text { No difference: } \\
\text { after excluding dropouts and } \\
\text { those with medication } \\
\text { changes, CPAP resulted in a } \\
\text { reduction in HbA1c of } 0.4 \% \\
\text { Significant reduction in systolic } \\
\text { and diastolic BP ( } 10 \text { and } \\
6 \mathrm{~mm} \mathrm{Hg} \text {, respectively) }\end{array}$ \\
\hline $\begin{array}{l}\text { Martinez- } \\
\text { Ceron } \\
\text { et } \mathrm{al}^{104} / 2016\end{array}$ & $\begin{array}{l}50 \\
26 \text { CPAP } \\
24 \text { no } \\
\text { treatment }\end{array}$ & $\begin{array}{l}\text { Parallel } \\
\text { group }\end{array}$ & $\mathrm{AHI} \geq 5$ & $\begin{array}{l}\text { CPAP: HbA1c, } 7.6 \% \\
\text { No treatment: } \\
\text { HbA1c, 7.6\% } \\
\text { (58\% OHA, } \\
36 \% \text { insulin, } \\
6 \% \text { OHA and } \\
\text { insulin) }\end{array}$ & $6 \mathrm{mo}$ & CPAP, 5.2 & $\begin{array}{l}\text { HbA1c, fasting } \\
\text { glucose and } \\
\text { insulin, insulin } \\
\text { sensitivity (HOMA } \\
\text { and QUICKI) }\end{array}$ & $\begin{array}{l}\text { Decreased } \mathrm{HbA} 1 \mathrm{c} \text { levels, mean } \\
\text { difference, } 0.4 \% \\
\text { Decreased fasting insulin levels } \\
\text { Improved insulin sensitivity } \\
\text { decreased IL-1 } \beta, \text { IL- } 6 \text {, and } \\
\text { adiponectin }\end{array}$ \\
\hline $\begin{array}{l}\text { Mokhlesi } \\
\text { et } \mathrm{al}^{103} / 2016\end{array}$ & $\begin{array}{l}19 \\
13 \text { assigned } \\
\text { to } \\
\text { therapeutic } \\
\text { CPAP } \\
6 \text { assigned to } \\
\text { sham CPAP }\end{array}$ & $\begin{array}{l}\text { Parallel } \\
\text { group }\end{array}$ & $\mathrm{AHI} \geq 5$ & $\begin{array}{l}\text { CPAP: HbA1c, } \\
7.3 \%(46 \% \text { diet } \\
\text { controlled, } \\
54 \% \text { OHA) } \\
\text { Sham: HbA1c, } \\
\text { 7.0\% (33\% diet } \\
\text { controlled, } \\
66 \% \text { OHA) }\end{array}$ & $\begin{array}{l}1 \text { wk in } \\
\text { laboratory } \\
\text { proof of } \\
\text { concept }\end{array}$ & $\begin{array}{l}\text { CPAP, } 7.9 \\
\text { Sham, } 7.9\end{array}$ & $\begin{array}{l}\text { Plasma glucose } \\
\text { measured by } 24-\mathrm{h} \\
\text { blood sampling }\end{array}$ & $\begin{array}{l}\text { Decreased plasma glucose, } \\
\text { predominantly at night and } \\
\text { morning fasting, reduced } \\
\text { serum insulin (nonsignificant } \\
\text { trend) }\end{array}$ \\
\hline
\end{tabular}




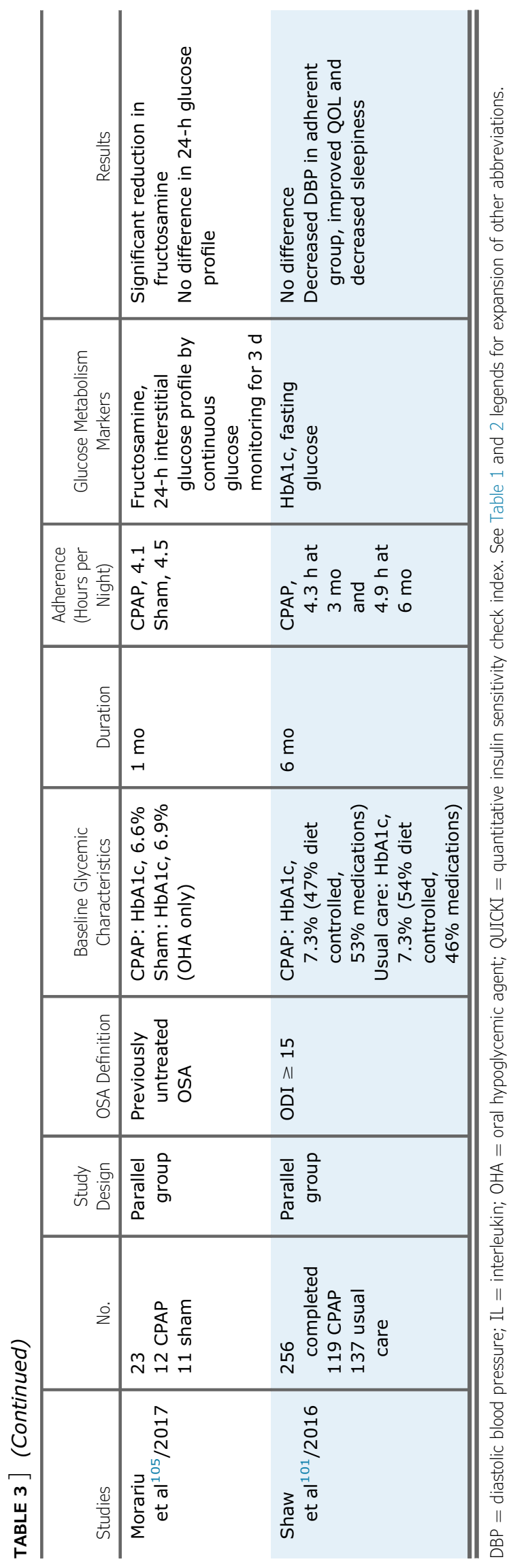

(adjusted mean, $-0.7 \%$ vs $-0.2 \%),{ }^{114}$ although the changes in $\mathrm{HbA1c}$ levels were not related to the changes in AHI. Since overweight/obesity is a significant problem in patients with type 2 diabetes, some of the newer diabetes medications have focused on weight neutral or weight loss effects, along with improving glycemic control. The glucagon-like peptide 1 (GLP-1) receptor agonist liraglutide has been approved for diabetes as well as weight reduction. Compared with placebo, liraglutide $3.0 \mathrm{mg}$ daily administered subcutaneously for 32 weeks in obese participants without diabetes and moderate to severe OSA resulted in a greater reduction in weight (mean difference, $-4.2 \%$ ), OSA severity (mean difference in AHI, -6.1 events/h), and HbA1c levels. ${ }^{115}$ Finally, bariatric surgery (or metabolic surgery) is an effective treatment for both diabetes and OSA. It is now a recommended treatment for patients with diabetes and BMI $\geq 40 \mathrm{~kg} / \mathrm{m}^{2}$ or 35.0 to $35.9 \mathrm{~kg} / \mathrm{m}^{2}$ with inadequate glycemic control despite lifestyle changes and optimal medical therapy. ${ }^{88}$ Bariatric surgery can significantly improve type 2 diabetes and reverse it in a significant proportion of patients. ${ }^{116}$ In a randomized controlled trial of gastric banding vs a conventional weight loss program in which one-third of participants had type 2 diabetes, those randomized to gastric banding lost, on average, $27.8 \mathrm{~kg}$ (95\% CI, 20.9-34.7 kg) over 2 years. This degree of weight loss led to a reduction in AHI of 25.5 events/h (95\% CI, 14.2-36.7 events/h). ${ }^{117}$ In a meta-analysis of 12 studies that included 342 patients, Greenburg et $\mathrm{al}^{118}$ reported that bariatric surgery led to significant weight loss, with a mean reduction in BMI from $55.3 \mathrm{~kg} / \mathrm{m}^{2}$ to $37.7 \mathrm{~kg} / \mathrm{m}^{2}$. This robust weight loss was accompanied by a $71 \%$ reduction in the AHI from a baseline value of 55 events/h (95\% CI, 49-60) to 16 events/h (95\% CI, 1319). However, only $38 \%$ achieved cure defined as an AHI $<5$ events/h. In contrast, $62 \%$ of patients had residual OSA, with a mean AHI of 16 events/h. ${ }^{118}$ Taken together, bariatric surgery can lead to significant improvement in OSA and type 2 diabetes, although patients need to be followed clinically to assess the impact of weight loss on the severity of OSA.

In summary, the results of studies on the effect of CPAP on glycemic control remain conflicting. However, other favorable effects of CPAP support its use in patients with diabetes and OSA, particularly in symptomatic patients. Increasing evidence suggests that patients with type 2 diabetes and severe OSA who are highly adherent to CPAP therapy may have a greater likelihood of deriving metabolic benefit. ${ }^{44,103,104,119}$ Although such a high level 
of CPAP adherence may be difficult to attain for many patients, novel and better-tolerated therapeutic approaches may eventually allow us to effectively treat OSA during the entire sleep period. It is imperative that clinicians caring for these patients emphasize interventions designed to achieve weight loss and increase in physical activity. Undoubtedly, the ongoing clinical trials (e- Table 1) will shed more light on the impact of CPAP therapy on glycemic control and diabetic complications in patients with OSA.

\section{Type 1 Diabetes}

Type 1 diabetes accounts for $5 \%$ to $10 \%$ of all diabetes and differs from type 2 diabetes in its pathogenesis. Although disease onset can occur at any age, the peak incidence is typically around ages 10 to 14 years. ${ }^{120}$ Thus far, OSA has not been reported to be a risk factor for incident type 1 diabetes. However, in patients with type 1 diabetes, the prevalence of OSA is significantly higher than in the general population. In a meta-analysis of four studies $\left(\mathrm{N}=186\right.$, mean BMI, $\left.22.9-25.8 \mathrm{~kg} / \mathrm{m}^{2}\right)$, the prevalence of OSA (AHI $\geq 5$ events/h or pathologic oximetry recordings) was found in $52 \%$ of the cases. ${ }^{56}$ This is consistent with a recent large study that found OSA in $46 \%$ of the 200 participants with type 1 diabetes (mean BMI, 24.4-26.4 kg/m $\mathrm{m}^{2}$ ). ${ }^{53}$ Therefore, obesity is unlikely to explain these findings. Studies have suggested that the presence of neuropathy, especially autonomic neuropathy, is a risk factor for OSA in type 1 diabetes. ${ }^{53,55,121}$ Neuropathy may compromise upper airway reflexes and control of the pharyngeal dilator muscles, predisposing patients to obstructive events. ${ }^{122}$ Patients with type 1 diabetes and OSA have significantly higher rates of autonomic neuropathy ( $37 \%$ vs $21 \%$ ) as well as peripheral neuropathy ( $58 \%$ vs $26 \%$ ) compared with those without OSA. ${ }^{53}$ The current limited data do not reveal an association between OSA and glycemic control in patients with type 1 diabetes, although a trend was observed in those with moderate to severe OSA. ${ }^{56}$

\section{Future Directions}

Growing evidence suggests a strong link between OSA and markers of glucose metabolism. Future studies should explore novel interventions or include strategies to maximize adherence with current treatment modalities (ie, CPAP) to treat OSA during the entire sleep period. This will allow an accurate evaluation of the effect of OSA therapy on glucose metabolism and diabetic complications in prediabetes and type 2 diabetes. Epidemiology of OSA in type 1 diabetes, its relation to glycemic control, and the effects of CPAP treatment remain to be explored. We review the association between OSA and complications of type 2 diabetes, and gestational diabetes in e-Appendix 1.

\section{Acknowledgments}

Financial/nonfinancial disclosures: The authors have reported to CHEST the following: B. M. is supported by National Institutes of Health grant R01HL119161 and has served on the advisory board of Itamar Medical. S. R. receives a research grant from Merck Sharp and Dohme and honoraria from Sanofi Aventis, Medtronic, Novo Nordisk, and research equipment support from ResMed, Thailand.

Other contributions: We would like to thank Thunyarat Anothaisintawee, MD, PhD, Department of Family Medicine and the Section for Clinical Epidemiology and Statistics, Faculty of Medicine Ramathibodi Hospital, Mahidol University, Bangkok, Thailand, for her statistical assistance.

Additional information: The e-Appendix and e-Table can be found in the Supplemental Materials section of the online article.

\section{References}

1. Heinzer R, Vat S, Marques-Vidal P, et al. Prevalence of sleepdisordered breathing in the general population: the HypnoLaus study. Lancet Respir Med. 2015;3(4):310-318.

2. Duran J, Esnaola S, Rubio R, et al. Obstructive sleep apneahypopnea and related clinical features in a population-based sample of subjects aged 30 to 70 yr. Am J Respir Crit Care Med. 2001;163(3 Pt 1):685-689.

3. Bixler EO, Vgontzas AN, Ten HT, et al. Effects of age on sleep apnea in men: I. Prevalence and severity. Am J Respir Crit Care Med. 1998;157(1):144-148.

4. Young T, Palta M, Dempsey J, et al. The occurrence of sleepdisordered breathing among middle-aged adults. $N$ Engl J Med. 1993;328(17):1230-1235.

5. Bixler EO, Vgontzas AN, Lin HM, et al. Prevalence of sleepdisordered breathing in women: effects of gender. Am J Respir Crit Care Med. 2001;163(3 Pt 1):608-613.

6. Peppard PE, Young T, Barnet JH, et al. Increased prevalence of sleep-disordered breathing in adults. Am J Epidemiol. 2013;177(9): 1006-1014.

7. Centers for Disease Control and Prevention. Diabetes 2014 report card. https://www.cdc.gov/diabetes/library/reports/reportcard. html. Accessed June 16, 2017.

8. Knowler WC, Barrett-Connor E, Fowler SE, et al. Reduction in the incidence of type 2 diabetes with lifestyle intervention or metformin. N Engl J Med. 2002;346(6):393-403.

9. Punjabi NM, Sorkin JD, Katzel LI, et al. Sleep-disordered breathing and insulin resistance in middle-aged and overweight men. Am J Respir Crit Care Med. 2002;165(5):677-682.

10. Punjabi NM, Beamer BA. Alterations in glucose disposal in sleepdisordered breathing. Am J Respir Crit Care Med. 2009;179(3): 235-240.

11. Iftikhar IH, Hoyos CM, Phillips CL, et al. Meta-analyses of the association of sleep apnea with insulin resistance, and the effects of CPAP on HOMA-IR, adiponectin, and visceral adipose fat. J Clin Sleep Med. 2015;11(4):475-485.

12. Ip MS, Lam B, Ng MM, et al. Obstructive sleep apnea is independently associated with insulin resistance. Am J Respir Crit Care Med. 2002;165(5):670-676.

13. Spiegel K, Leproult R, Van Cauter E. Impact of sleep debt on metabolic and endocrine function. Lancet. 1999;354(9188):1435-1439.

14. Nedeltcheva AV, Kessler L, Imperial J, et al. Exposure to recurrent sleep restriction in the setting of high caloric intake and physical inactivity results in increased insulin resistance and reduced glucose tolerance. J Clin Endocrinol Metab. 2009;94(9): 3242-3250. 
15. Buxton OM, Pavlova M, Reid EW, et al. Sleep restriction for 1 week reduces insulin sensitivity in healthy men. Diabetes. 2010;59(9): 2126-2133.

16. Broussard JL, Ehrmann DA, Van Cauter E, et al. Impaired insulin signaling in human adipocytes after experimental sleep restriction: a randomized, crossover study. Ann Intern Med. 2012;157(8): 549-557.

17. Donga E, van DM, van Dijk JG, et al. A single night of partial sleep deprivation induces insulin resistance in multiple metabolic pathways in healthy subjects. J Clin Endocrinol Metab. 2010;95(6): 2963-2968.

18. Cedernaes J, Lampola L, Axelsson EK, et al. A single night of partial sleep loss impairs fasting insulin sensitivity but does not affect cephalic phase insulin release in young men. J Sleep Res. 2016;25(1): 5-10.

19. Stamatakis KA, Punjabi NM. Effects of sleep fragmentation on glucose metabolism in normal subjects. Chest. 2010;137(1):95-101.

20. Tasali E, Leproult R, Ehrmann DA, et al. Slow-wave sleep and the risk of type 2 diabetes in humans. Proc Natl Acad Sci US A. 2008;105(3):1044-1049.

21. Herzog N, Jauch-Chara K, Hyzy F, et al. Selective slow wave sleep but not rapid eye movement sleep suppression impairs morning glucose tolerance in healthy men. Psychoneuroendocrinology. 2013;38(10):2075-2082.

22. Louis M, Punjabi NM. Effects of acute intermittent hypoxia on glucose metabolism in awake healthy volunteers. J Appl Physiol. 2009;106(5):1538-1544.

23. Reutrakul S, Van Cauter E. Interactions between sleep, circadian function, and glucose metabolism: implications for risk and severity of diabetes. Ann N Y Acad Sci. 2014;1311:151-173.

24. Newhouse LP, Joyner MJ, Curry TB, et al. Three hours of intermittent hypoxia increases circulating glucose levels in healthy adults. Physiol Rep. 2017;5(1).

25. Oltmanns KM, Gehring H, Rudolf S, et al. Hypoxia causes glucose intolerance in humans. Am J Respir Crit Care Med. 2004;169(11): 1231-1237.

26. Somers VK, Dyken ME, Mark AL, et al. Sympathetic-nerve activity during sleep in normal subjects. N Engl J Med. 1993;328(5): 303-307.

27. Somers VK, Dyken ME, Clary MP, et al. Sympathetic neural mechanisms in obstructive sleep apnea. J Clin Invest. 1995;96(4): 1897-1904.

28. Narkiewicz K, Kato M, Phillips BG, et al. Nocturnal continuous positive airway pressure decreases daytime sympathetic traffic in obstructive sleep apnea. Circulation. 1999;100(23):2332-2335.

29. Bloom SR, Edwards AV, Hardy RN. The role of the autonomic nervous system in the control of glucagon, insulin and pancreatic polypeptide release from the pancreas. J Physiol. 1978;280:9-23.

30. Lembo G, Capaldo B, Rendina V, et al. Acute noradrenergic activation induces insulin resistance in human skeletal muscle. Am J Physiol. 1994;266(2 Pt 1):E242-E247.

31. Nonogaki K. New insights into sympathetic regulation of glucose and fat metabolism. Diabetologia. 2000;43(5):533-549.

32. Ahren B, Holst JJ. The cephalic insulin response to meal ingestion in humans is dependent on both cholinergic and noncholinergic mechanisms and is important for postprandial glycemia. Diabetes. 2001;50(5):1030-1038.

33. Balks HJ, Holst JJ, von zur MA, et al. Rapid oscillations in plasma glucagon-like peptide-1 (GLP-1) in humans: cholinergic control of GLP-1 secretion via muscarinic receptors. J Clin Endocrinol Metab. 1997;82(3):786-790.

34. Hansen L, Lampert S, Mineo H, et al. Neural regulation of glucagon-like peptide-1 secretion in pigs. Am J Physiol Endocrinol Metab. 2004;287(5):E939-E947.

35. Pamidi S, Wroblewski K, Stepien M, et al. Eight hours of nightly continuous positive airway pressure treatment of obstructive sleep apnea improves glucose metabolism in patients with prediabetes. A randomized controlled trial. Am J Respir Crit Care Med. 2015;192(1):96-105.
36. Ziegler MG, Mills PJ, Loredo JS, et al. Effect of continuous positive airway pressure and placebo treatment on sympathetic nervous activity in patients with obstructive sleep apnea. Chest. 2001;120(3): 887-893.

37. Kohler M, Pepperell JC, Casadei B, et al. CPAP and measures of cardiovascular risk in males with OSAS. Eur Respir J. 2008;32(6): 1488-1496.

38. Myhill PC, Davis WA, Peters KE, et al. Effect of continuous positive airway pressure therapy on cardiovascular risk factors in patients with type 2 diabetes and obstructive sleep apnea. J Clin Endocrinol Metab. 2012;97(11):4212-4218.

39. Mokhlesi B, Grimaldi D, Beccuti G, et al. Effect of one week of CPAP treatment of obstructive sleep apnoea on 24-hour profiles of glucose, insulin and counter-regulatory hormones in type 2 diabetes. Diabetes Obes Metab. 2017;19(3):452-456.

40. Yokoe T, Alonso LC, Romano LC, et al. Intermittent hypoxia reverses the diurnal glucose rhythm and causes pancreatic beta-cell replication in mice. J Physiol. 2008;586(3):899-911.

41. Xu J, Long YS, Gozal D, et al. Beta-cell death and proliferation after intermittent hypoxia: role of oxidative stress. Free Radic Biol Med. 2009;46(6):783-790.

42. Wang N, Khan SA, Prabhakar NR, et al. Impairment of pancreatic beta-cell function by chronic intermittent hypoxia. Exp Physiol. 2013;98(9):1376-1385.

43. Polak J, Shimoda LA, Drager LF, et al. Intermittent hypoxia impairs glucose homeostasis in C57BL6/J mice: partial improvement with cessation of the exposure. Sleep. 2013;36(10):1483-1490.

44. Grimaldi D, Beccuti G, Touma C, et al. Association of obstructive sleep apnea in REM sleep with reduced glycemic control in type 2 diabetes: therapeutic implications. Diabetes Care. 2014;37(2):355363.

45. Chami HA, Gottlieb DJ, Redline S, et al. Association between glucose metabolism and sleep-disordered breathing during REM sleep. Am J Respir Crit Care Med. 2015;192(9):1118-1126.

46. Fendri S, Rose D, Myambu S, et al. Nocturnal hyperglycaemia in type 2 diabetes with sleep apnoea syndrome. Diabetes Res Clin Pract. 2011;91(1):e21-e23.

47. Bialasiewicz P, Czupryniak L, Pawlowski M, et al. Sleep disordered breathing in REM sleep reverses the downward trend in glucose concentration. Sleep Med. 2011;12(1):76-82.

48. Resnick HE, Redline S, Shahar E, et al. Diabetes and sleep disturbances: findings from the Sleep Heart Health Study. Diabetes Care. 2003;26(3):702-709.

49. Bottini P, Redolfi S, Dottorini ML, et al. Autonomic neuropathy increases the risk of obstructive sleep apnea in obese diabetics. Respiration. 2008;75(3):265-271.

50. Sanders MH, Givelber R. Sleep disordered breathing may not be an independent risk factor for diabetes, but diabetes may contribute to the occurrence of periodic breathing in sleep. Sleep Med. 2003;4(4): 349-350.

51. Bottini P, Dottorini ML, Cristina CM, et al. Sleep-disordered breathing in nonobese diabetic subjects with autonomic neuropathy. Eur Respir J. 2003;22(4):654-660.

52. Lecube A, Sampol G, Hernandez C, et al. Characterization of sleep breathing pattern in patients with type 2 diabetes: Sweet Sleep Study. PLoS One. 2015;10(3):e0119073.

53. Banghoej AM, Nerild HH, Kristensen PL, et al. Obstructive sleep apnoea is frequent in patients with type 1 diabetes. $J$ Diabetes Complicat. 2017;31(1):156-161.

54. Borel AL, Benhamou PY, Baguet JP, et al. High prevalence of obstructive sleep apnoea syndrome in a type 1 diabetic adult population: a pilot study. Diabet Med. 2010;27(11):1328-1329.

55. Janovsky CC, Rolim LC, de Sa JR, et al. Cardiovascular autonomic neuropathy contributes to sleep apnea in young and lean type 1 diabetes mellitus patients. Front Endocrinol (Lausanne). 2014;5:119.

56. Reutrakul S, Thakkinstian A, Anothaisintawee T, et al. Sleep characteristics in type 1 diabetes and associations with glycemic control: systematic review and meta-analysis. Sleep Med. 2016;23: 26-45. 
57. Lecube A, Ciudin A, Sampol G, et al. Effect of glycemic control on nocturnal arterial oxygen saturation: a case-control study in type 2 diabetic patients. J Diabetes. 2015;7(1):133-138.

58. Appleton SL, Vakulin A, McEvoy RD, et al. Nocturnal hypoxemia and severe obstructive sleep apnea are associated with incident type 2 diabetes in a population cohort of men. J Clin Sleep Med. 2015;11(6):609-614.

59. Kendzerska T, Gershon AS, Hawker G, et al. Obstructive sleep apnea and incident diabetes. A historical cohort study. Am J Respir Crit Care Med. 2014;190(2):218-225.

60. Marshall NS, Wong KK, Phillips CL, et al. Is sleep apnea an independent risk factor for prevalent and incident diabetes in the Busselton Health Study? J Clin Sleep Med. 2009;5(1):15-20.

61. Muraki I, Tanigawa T, Yamagishi K, et al. Nocturnal intermittent hypoxia and metabolic syndrome; the effect of being overweight: the CIRCS study. J Atheroscler Thromb. 2010;17(4):369-377.

62. Nagayoshi M, Punjabi NM, Selvin E, et al. Obstructive sleep apnea and incident type 2 diabetes. Sleep Med. 2016;25:156-161.

63. Botros N, Concato J, Mohsenin V, et al. Obstructive sleep apnea as a risk factor for type 2 diabetes. Am J Med. 2009;122(12): 1122-1127.

64. Boyko EJ, Seelig AD, Jacobson IG, et al. Sleep characteristics, mental health, and diabetes risk: a prospective study of U.S. military service members in the Millennium Cohort Study. Diabetes Care. 2013;36(10):3154-3161.

65. Celen YT, Hedner J, Carlson J, et al. Impact of gender on incident diabetes mellitus in obstructive sleep apnea: a 16-year follow-up. J Clin Sleep Med. 2010;6(3):244-250.

66. Lindberg E, Theorell-Haglow J, Svensson M, et al. Sleep apnea and glucose metabolism: a long-term follow-up in a community-based sample. Chest. 2012;142(4):935-942.

67. Reichmuth KJ, Austin D, Skatrud JB, et al. Association of sleep apnea and type II diabetes: a population-based study. Am J Respir Crit Care Med. 2005;172(12):1590-1595.

68. Anothaisintawee T, Reutrakul S, Van Cauter E, et al. Sleep disturbances compared to traditional risk factors for diabetes development: Systematic review and meta-analysis. Sleep Med Rev. 2015;30:11-24.

69. Al-Delaimy WK, Manson JE, Willett WC, et al. Snoring as a risk factor for type II diabetes mellitus: a prospective study. Am J Epidemiol. 2002;155(5):387-393.

70. Strand LB, Carnethon M, Biggs ML, et al. Sleep disturbances and glucose metabolism in older adults: the cardiovascular health study. Diabetes Care. 2015;38(11):2050-2058.

71. Elmasry A, Janson C, Lindberg E, et al. The role of habitual snoring and obesity in the development of diabetes: a 10-year follow-up study in a male population. J Intern Med. 2000;248(1):13-20.

72. Einhorn D, Stewart DA, Erman MK, et al. Prevalence of sleep apnea in a population of adults with type 2 diabetes mellitus. Endocr Pract. 2007;13(4):355-362.

73. Foster GD, Sanders MH, Millman R, et al. Obstructive sleep apnea among obese patients with type 2 diabetes. Diabetes Care. 2009;32(6):1017-1019.

74. Laaban JP, Daenen S, Leger D, et al. Prevalence and predictive factors of sleep apnoea syndrome in type 2 diabetic patients. Diabetes Metab. 2009;35(5):372-377.

75. Aronsohn RS, Whitmore H, Van Cauter E, et al. Impact of untreated obstructive sleep apnea on glucose control in type 2 diabetes. Am J Respir Crit Care Med. 2010;181(5):507-513.

76. Lam DC, Lui MM, Lam JC, et al. Prevalence and recognition of obstructive sleep apnea in Chinese patients with type 2 diabetes mellitus. Chest. 2010;138(5):1101-1107.

77. Tahrani AA, Ali A, Raymond NT, et al. Obstructive sleep apnea and diabetic neuropathy: a novel association in patients with type 2 diabetes. Am J Respir Crit Care Med. 2012;186(5):434-441.

78. Hanis CL, Redline S, Cade BE, et al. Beyond type 2 diabetes, obesity and hypertension: an axis including sleep apnea, left ventricular hypertrophy, endothelial dysfunction, and aortic stiffness among
Mexican Americans in Starr County. Texas. Cardiovasc Diabetol. 2016;15:86.

79. Westlake K, Plihalova A, Pretl M, et al. Screening for obstructive sleep apnea syndrome in patients with type 2 diabetes mellitus: a prospective study on sensitivity of Berlin and STOP-Bang questionnaires. Sleep Med. 2016;26:71-76.

80. Siwasaranond N, Nimitphong H, Saetung S, et al. Shorter sleep duration is associated with poorer glycemic control in type 2 diabetes patients with untreated sleep-disordered breathing. Sleep Breath. 2016;20(2):569-574.

81. Zhang $\mathrm{P}$, Zhang R, Zhao F, et al. The prevalence and characteristics of obstructive sleep apnea in hospitalized patients with type 2 diabetes in China. J Sleep Res. 2016;25(1):39-46.

82. Heffner JE, Rozenfeld Y, Kai M, et al. Prevalence of diagnosed sleep apnea among patients with type 2 diabetes in primary care. Chest. 2012;141(6):1414-1421.

83. Mahmood K, Akhter N, Eldeirawi K, et al. Prevalence of type 2 diabetes in patients with obstructive sleep apnea in a multi-ethnic sample. J Clin Sleep Med. 2009;5(3):215-221.

84. Kent BD, Grote L, Ryan S, et al. Diabetes mellitus prevalence and control in sleep-disordered breathing: the European Sleep Apnea Cohort (ESADA) study. Chest. 2014;146(4):982-990.

85. Pillai A, Warren G, Gunathilake W, et al. Effects of sleep apnea severity on glycemic control in patients with type 2 diabetes prior to continuous positive airway pressure treatment. Diabetes Technol Ther. 2011;13(9):945-949.

86. Priou P, Le VM, Meslier N, et al. Association between obstructive sleep apnea severity and glucose control in patients with untreated versus treated diabetes. J Sleep Res. 2015;24(4): 425-431.

87. Shaw JE, Punjabi NM, Wilding JP, et al. Sleep-disordered breathing and type 2 diabetes: a report from the International Diabetes Federation Taskforce on Epidemiology and Prevention. Diabetes Res Clin Pract. 2008;81(1):2-12.

88. American Diabetes Association. Standards of Medical Care in Diabetes-2017. Diabetes Care. 2017;40(Suppl 1):S1-S142.

89. Coughlin SR, Mawdsley L, Mugarza JA, et al. Cardiovascular and metabolic effects of CPAP in obese males with OSA. Eur Respir J. 2007;29(4):720-727.

90. Comondore VR, Cheema R, Fox J, et al. The impact of CPAP on cardiovascular biomarkers in minimally symptomatic patients with obstructive sleep apnea: a pilot feasibility randomized crossover trial. Lung. 2009;187(1):17-22.

91. Nguyen PK, Katikireddy CK, McConnell MV, et al. Nasal continuous positive airway pressure improves myocardial perfusion reserve and endothelial-dependent vasodilation in patients with obstructive sleep apnea. J Cardiovasc Magn Reson. 2010;12:50.

92. Kohler M, Stoewhas AC, Ayers L, et al. Effects of continuous positive airway pressure therapy withdrawal in patients with obstructive sleep apnea: a randomized controlled trial. Am J Respir Crit Care Med. 2011;184(10):1192-1199.

93. Hoyos CM, Killick R, Yee BJ, et al. Cardiometabolic changes after continuous positive airway pressure for obstructive sleep apnoea: a randomised sham-controlled study. Thorax. 2012;67(12): 1081-1089.

94. Sivam S, Phillips CL, Trenell MI, et al. Effects of 8 weeks of continuous positive airway pressure on abdominal adiposity in obstructive sleep apnoea. Eur Respir J. 2012;40(4):913-918.

95. Kritikou I, Basta M, Vgontzas AN, et al. Sleep apnoea, sleepiness, inflammation and insulin resistance in middle-aged males and females. Eur Respir J. 2014;43(1):145-155.

96. Lam JC, Lam B, Yao TJ, et al. A randomised controlled trial of nasal continuous positive airway pressure on insulin sensitivity in obstructive sleep apnoea. Eur Respir J. 2010;35(1):138-145.

97. Salord N, Fortuna AM, Monasterio C, et al. A randomized controlled trial of continuous positive airway pressure on glucose tolerance in obese patients with obstructive sleep apnea. Sleep. 2016;39(1):35-41. 
98. Chirinos JA, Gurubhagavatula I, Teff K, et al. CPAP, weight loss, or both for obstructive sleep apnea. N Engl J Med. 2014;370(24): 2265-2275.

99. Weinstock TG, Wang X, Rueschman M, et al. A controlled trial of CPAP therapy on metabolic control in individuals with impaired glucose tolerance and sleep apnea. Sleep. 2012;35(5):617-625B.

100. Chen L, Kuang J, Pei JH, et al. Continuous positive airway pressure and diabetes risk in sleep apnea patients: A systemic review and meta-analysis. Eur J Intern Med. 2017;39:39-50.

101. Shaw JE, Punjabi NM, Naughton MT, et al. The effect of treatment of obstructive sleep apnea on glycemic control in type 2 diabetes. Am J Respir Crit Care Med. 2016;194(4):486-492.

102. West SD, Nicoll DJ, Wallace TM, et al. Effect of CPAP on insulin resistance and $\mathrm{HbAlc}$ in men with obstructive sleep apnoea and type 2 diabetes. Thorax. 2007;62(11):969-974.

103. Mokhlesi B, Grimaldi D, Beccuti G, et al. Effect of one week of 8hour nightly continuous positive airway pressure treatment of obstructive sleep apnea on glycemic control in type 2 diabetes: a proof-of-concept study. Am J Respir Crit Care Med. 2016;194(4): 516-519.

104. Martinez-Ceron E, Barquiel B, Bezos AM, et al. Effect of continuous positive airway pressure on glycemic control in patients with obstructive sleep apnea and type 2 diabetes. a randomized clinical trial. Am J Respir Crit Care Med. 2016;194(4):476-485.

105. Morariu EM, Chasens ER, Strollo PJ Jr, et al. Effect of continuous positive airway pressure (CPAP) on glycemic control and variability in type 2 diabetes. Sleep Breath. 2017;21(1):145-147.

106. Lam JCM, Lai AY, Tam TCC, et al. CPAP therapy for patients with sleep apnea and type 2 diabetes mellitus improves control of blood pressure. Sleep Breath. 2017;21(2):377-386.

107. Intensive blood-glucose control with sulphonylureas or insulin compared with conventional treatment and risk of complications in patients with type 2 diabetes (UKPDS 33). UK Prospective Diabetes Study (UKPDS) Group. Lancet. 1998;352(9131):837-853.

108. Dawson A, Abel SL, Loving RT, et al. CPAP therapy of obstructive sleep apnea in type 2 diabetics improves glycemic control during sleep. J Clin Sleep Med. 2008;4(6):538-542.

109. Pallayova M, Donic V, Tomori Z. Beneficial effects of severe sleep apnea therapy on nocturnal glucose control in persons with type 2 diabetes mellitus. Diabetes Res Clin Pract. 2008;81(1):e8-e11.
110. Babu AR, Herdegen J, Fogelfeld L, et al. Type 2 diabetes, glycemic control, and continuous positive airway pressure in obstructive sleep apnea. Arch Intern Med. 2005;165(4):447-452.

111. Guest JF, Panca M, Sladkevicius E, et al. Clinical outcomes and cost-effectiveness of continuous positive airway pressure to manage obstructive sleep apnea in patients with type 2 diabetes in the U.K. Diabetes Care. 2014;37(5):1263-1271.

112. Prasad B, Carley DW, Krishnan JA, et al. Effects of positive airway pressure treatment on clinical measures of hypertension and type 2 diabetes. J Clin Sleep Med. 2012;8(5):481-487.

113. Jullian-Desayes I, Joyeux-Faure M, Tamisier R, et al. Impact of obstructive sleep apnea treatment by continuous positive airway pressure on cardiometabolic biomarkers: a systematic review from sham CPAP randomized controlled trials. Sleep Med Rev. 2015;21: 23-38.

114. Foster GD, Borradaile KE, Sanders MH, et al. A randomized study on the effect of weight loss on obstructive sleep apnea among obese patients with type 2 diabetes: the Sleep AHEAD study. Arch Intern Med. 2009;169(17):1619-1626.

115. Blackman A, Foster GD, Zammit G, et al. Effect of liraglutide 3. $0 \mathrm{mg}$ in individuals with obesity and moderate or severe obstructive sleep apnea: the SCALE Sleep Apnea randomized clinical trial. Int J Obes (Lond). 2016;40(8):1310-1319.

116. Schauer PR, Bhatt DL, Kirwan JP, et al. Bariatric Surgery versus intensive medical therapy for diabetes-5-year outcomes. $N$ Engl J Med. 2017;376(7):641-651.

117. Dixon JB, Schachter LM, O'Brien PE, et al. Surgical vs conventional therapy for weight loss treatment of obstructive sleep apnea: a randomized controlled trial. JAMA. 2012;308(11):1142-1149.

118. Greenburg DL, Lettieri CJ, Eliasson AH. Effects of surgical weight loss on measures of obstructive sleep apnea: a meta-analysis. Am J Med. 2009;122(6):535-542.

119. Kaur A, Mokhlesi B. The effect of OSA therapy on glucose metabolism: it's all about cpap adherence! J Clin Sleep Med. 2017;13(3):365-367.

120. Maahs DM, West NA, Lawrence JM, et al. Epidemiology of type 1 diabetes. Endocrinol Metab Clin North Am. 2010;39(3):481-497.

121. Mondini S, Guilleminault C. Abnormal breathing patterns during sleep in diabetes. Ann Neurol. 1985;17(4):391-395.

122. Guilleminault C, Briskin JG, Greenfield MS, et al. The impact of autonomic nervous system dysfunction on breathing during sleep. Sleep. 1981;4(3):263-278. 